\title{
The influence of ecosystems on the entrepreneurship process: a comparison across developed and developing economies
}

\author{
Maribel Guerrero $\mathbb{D}$ - Francisco Liñán $(\mathbb{D})$ \\ F. Rafael Cáceres-Carrasco (D)
}

Accepted: 4 August 2020 / Published online: 21 August 2020

(C) The Author(s) 2020

\begin{abstract}
Over the past 30 years, the academic literature has legitimised the significant impact of environmental conditions on entrepreneurial activity. In the past 5 years, in particular, the academic debate has focused on the elements that configure entrepreneurship ecosystems and their influence on the creation of high-growth ventures. Previous studies have also recognised the heterogeneity of environmental conditions (including policies, support programs, funding, culture, professional infrastructure, university support, labour market, R\&D, and market dynamics) across regions/countries. Yet, an in-depth discussion is required to address how environmental conditions vary per entrepreneurial stage of enterprises within certain regions/countries, as well as how these conditions determine the technological factor of
\end{abstract}

\footnotetext{
M. Guerrero

Faculty of Economics and Business, Universidad del Desarrollo, Avenida la Plaza 680, Santiago, Chile

M. Guerrero $(\bowtie)$

Northumbria Centre for Innovation, Regional Transformation, and Entrepreneurship (iNCITE), Newcastle Business School

Northumbria Univesity, Sutherland Building, 2 Ellison Pl,

Newcastle upon Tyne NE1 8ST, UK

e-mail: maribel.guerrero@northumbria.ac.uk

F. Liñán · F. R. Cáceres-Carrasco

Department of Applied Economics I, Universidad de Sevilla, Av. Ramón y Cajal, 1, Sevilla 41018, Spain

F. Liñán

School of Management, Anglia Ruskin University, Cambridge Campus, East Rd, Cambridge CB1 1PT, UK
}

the entrepreneurial process. By reviewing the literature from 2000 to 2017, this paper analyses the environmental conditions that have influenced the transitions towards becoming potential entrepreneurs, nascent/new entrepreneurs, and established/consolidated entrepreneurs in both developed and developing economies. Our findings show why diversity in entrepreneurship and context is significant. Favourable conditions include professional support, incubators/accelerators, networking with multiple agents, and R\&D investments. Less favourable conditions include a lack of funding sources, labour market conditions, and social norms. Our paper contributes by proposing a research agenda and implications for stakeholders.

Keywords Entrepreneurship · Entrepreneurial process · Entrepreneurship ecosystems $\cdot$ Environmental conditions · Institutional economics · Socioeconomic stages $\cdot$ Research agenda

JEL classifications $\mathrm{L} 26 \cdot \mathrm{M} 13 \cdot \mathrm{D} 02 \cdot \mathrm{O} 33$

\section{Introduction}

In the past three decades, the literature has outlined the critical impact of environmental conditions on entrepreneurship and economic growth (Urbano et al. 2019). In the past 5 years especially, academic and public actors have focused on the configuration of thriving entrepreneurial ecosystems (Autio et al. 2014; Acs et al. 2017). It explains why the Silicon Valley entrepreneurial 
ecosystem has captured the attention of the international public policy community who wish to emulate it (Audretsch 2019). However, scholars worldwide argue that this model of entrepreneurship has several limitations when addressing the most compelling contemporary global problems.

By analysing the existing literature, it is possible to identify the conditions that act as drivers or barriers for entrepreneurship around the world. Although relevant insights can be gained, it is not yet clear which environmental conditions (policies, support programs, funding, culture, professional infrastructure, university support, labour market, infrastructure, networks, R\&D, and market dynamics) exert an influence during the exploration, exploitation, and consolidation of entrepreneurial initiatives (technological vs. non-technological) per type of economy (developed vs. developing economies) (Guerrero and Urbano 2019b). In this vein, Welter et al. (2017: p. 318) highlight that there is no single type of entrepreneurship, no ideal context, and no ideal type of entrepreneur. Therefore, differences matter; and where, when, and why those differences matter most need to be ascertained. It opens up the discussion on the diversity of contexts and types of entrepreneurship that should be understood by analysing their nature, richness, and dynamics (Welter 2011; Karlsson et al. 2019).

Inspired by this academic gap, in this paper, we review the previous literature in order to identify which environmental conditions have been affecting entrepreneurial processes per type of economy. Specifically, we analyse 67 manuscripts, published from 2000 to 2017 , that focus mainly on the barriers, facilitators, and triggers found in the developmental stages of diverse entrepreneurial types per socioeconomic context. Our analysis highlights the elements of entrepreneurial ecosystems associated with each developmental stage of diverse initiatives in developed and developing countries. Our results contribute to the academic discussion about the definitions/measures of entrepreneurship (Iversen et al. 2007; Henrekson and Sanandaji 2019), entrepreneurial process (Busenitz et al. 2014), entrepreneurial ecosystems (Acs et al. 2017; Audretsch 2019), diversity of entrepreneurship (Welter et al. 2017; Karlsson et al. 2019), and economic development (Urbano et al. 2019). A research agenda is proposed for the analysis of those gaps identified across the entrepreneurial processes and types of economy. Moreover, several contributions for stakeholders emerge from our results.

Following this introduction, the paper is structured as follows: Section 2 describes the theoretical foundations linking the entrepreneurial process with the environmental conditions. Section 3 presents the methodological design regarding data collection and analysis. Section 4 shows the insights obtained from the influence of the context on the entrepreneurial process across socioeconomic stages. Section 5 discusses the findings in light of previous studies and sets a research agenda. This section also provides several implications that have emerged from this study. Section 6 concludes by providing insights regarding the contributions to the academic debate in the field of entrepreneurship.

\section{Diversity in the entrepreneurial process and context}

According to Gartner (1990) and Morris et al. (1994), entrepreneurship encompasses the creation of enterprises, wealth, innovation, change, employment, value, and growth. Distinguishing between Schumpeterian entrepreneurship and other business activities may, therefore, facilitate the differentiation between low-impact and high-impact entrepreneurship in terms of outcomes, such as employment, sales, innovation, and the wealth of the founders (Henrekson and Sanandaji 2019). By understanding the diversity inherent in entrepreneurship (Iversen et al. 2007; Welter 2011; Dencker et al. 2019) and capturing the notion of Schumpeterian entrepreneurship (Henrekson and Sanandaji 2019; Karlsson et al. 2019), this research categorises entrepreneurship into either (a) non-Schumpeterian entrepreneurship or (b) Schumpeterian entrepreneurship. The first category (non-Schumpeterian entrepreneurship) is characterised by self-employment (individuals who do not generate employment and with outcomes that merely allow them to survive) and traditional entrepreneurs (individuals who generate lower impacts/outcomes). ${ }^{1}$ The second category (Schumpeterian entrepreneurship) comprises academic/graduate entrepreneurs (individuals who generate entrepreneurial innovations within a university or

\footnotetext{
${ }^{1}$ In this category, given the relevance of socio-demographic characteristics, we included a subcategory of self-employment and traditional entrepreneurship to distinguish owner demographic entrepreneurship (i.e. male and female, rural and urban, youth and senior, migrants and natives, social and profits, and others).
} 
after graduation) and innovative entrepreneurs (individuals who generate a technological-based venture that is looking for high-level impacts and outcomes).

Each type of entrepreneur experiences diverse stages both in their life cycle and in multiple contexts. Thus, the term "entrepreneurial process" describes a variety of stages, ranging from the exploration of a potential entrepreneurial initiative to the consolidation of a venture (Reynolds and White 1997). Several models have identified a series of phases that result in the creation/growth of a new venture (DeTienne 2010). Stevenson and Jarillo (1990) focus on the process by which individuals, either on their own or inside organisations, pursue opportunities without regard to the resources they currently control. Bygrave and Hofer (1991) describe all the functions, activities, and actions associated with the perception of opportunities and the creation of organisations to pursue them. Reynolds and White (1997) consider that the entrepreneurial process consists of four distinct phases: conception (the entire adult population); gestation (nascent entrepreneurs); infancy (fledgling new firms); and adolescence (established new firms). Korunka et al. (2003) and Davidsson (2006) refer to the entrepreneurial process as one that begins with the nascent entrepreneur and ends with the creation of the new venture. Entrepreneurship is a very complex process (Gartner et al. 2004). By taking the process view, entrepreneurship presents dynamic behaviours experienced under certain environmental conditions from whence opportunities and business ideas emerge (Jack and Anderson 2002). For instance, the main difficulty when studying context is that it varies across different socioeconomic conditions that interact and affect entrepreneurial behaviour (Jones and Coviello 2005). The environment influences not only the start-up rates at a population level but also the cultural, economic, and market factors that converge to enhance or inhibit entrepreneurship (Busenitz et al. 2003).

During the conception and gestation phases of the entrepreneurial process, the entrepreneur may begin to consider the idea of new venture creation, identify opportunities, and make decisions regarding time and resources (Reynolds and White 1997). In these phases, environmental factors are generally assumed to influence the emergence of new opportunities at the interface of individuals and teams (Hindle 2010; Busenitz et al. 2014; Liñán and Fayolle 2015; George et al. 2016). Busenitz et al. (2014) recognise that macroenvironmental conditions (new technologies, regulatory adjustments, climate shifts, and disasters) could influence the need for new opportunities to emerge in flux/stable periods. Similarly, George et al. (2016) show how environmental conditions create and moderate the relationships between individual behaviour and opportunity recognition. During the infancy phase, the new venture remains vulnerable and requires a significant amount of attention from the entrepreneur due to the liability of newness, smallness, and limited resources (i.e. specific knowledge, networks, customer relationships, and financing) (DeTienne 2010). Thus, the context plays an essential role in allowing access to those limited resources (Mueller 2006; Knox and Egbe 2018; Mergemeier et al. 2018; Wallmeroth et al. 2018). New entrepreneurs must scan the context to acquire and assimilate critical information for survival in a strongly competitive environment. If the venture survives, legitimacy increases, and the venture enters the adolescence phase (Cardon et al. 2005), where the natural orientation is towards growth in sales, employees, and market share or resource acquisition (Reynolds and White 1997). Over time, the venture may reach the maturity phase, wherein the founders may either continue to explore new opportunities or consider an exit strategy by seeking potential buyers in their environment (DeTienne 2010). This paper aims to address and answer the question: How does context affect each phase of the entrepreneurial process in terms of the type of entrepreneur and country?

\section{Methodology}

\subsection{Design}

Since our purpose is to analyse the influence of context across the entrepreneurial process, we have conducted a systematic search of the literature based on these elements (Gundolf and Filser 2013; Kraus et al. 2014; Xi et al. 2013). Every caution has been taken to ensure that this search is systematic, transparent, and replicable (Armitage and Keeble-Allen 2008; Lourenço and Jones 2006; Pittaway and Cope 2007; Tranfield et al. 2003). Only journal articles have been included, since these are considered validated knowledge (Podsakoff et al. 2005). In contrast, materials such as books, chapters, and conference papers have been excluded due to the variability in the peer-review process and their more restricted availability (Jones et al. 2011). 
Fig. 1 Entrepreneurial process

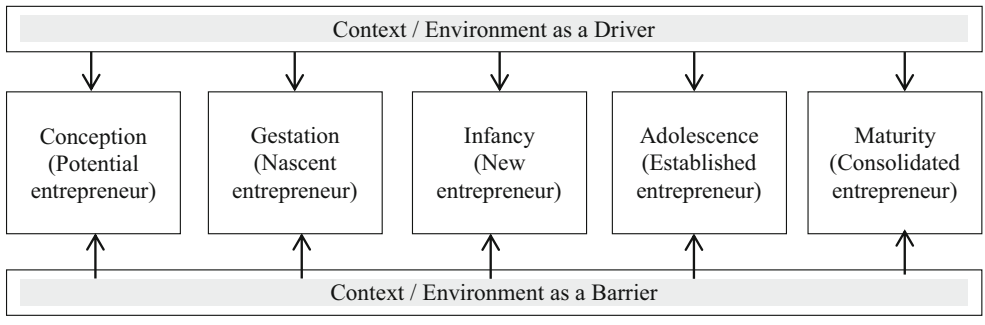

Source: The authors.

\subsection{Data collection}

Following the standard practice in previous research (Cornelius et al. 2006; Liñán and Fayolle 2015; Nabi et al. 2017), the data collection process consisted of four steps. First, using the Scopus database because of its more extensive journal coverage, we searched for articles published from 2000 to 2017 (both inclusive) in social sciences (including business, economics, and psychology). The screening criteria used the inherent diversity in the keywords: creation (or start-up, launch, or entry), entrepreneur (potential, nascent, or new venture), process (or action or longitudinal), and determining contextual factors (or barriers, facilitators, or triggers). As a result, we identified 742 publications. Second, by adopting the above screening criteria, other highly used databases were examined, such as Web of Science, ABI-Inform/ ProQuest, and Science Direct. In this process, we identified another 508 publications. Third, by adopting recommendations from Nabi et al. (2017), we reviewed the papers published in the top-five entrepreneurship journals ${ }^{2}$ to ensure that the core publications in the field were included. Thus, we identified a further 37 publications by analysing the specific role of environmental or contextual conditions on entrepreneurship but by excluding intrapreneurship and entrepreneurship education. Fourth, we eliminated duplicate papers, resulting in 986 publications in the initial pool of documents that focused on barriers, facilitators, or triggers found in the entrepreneurial process.

\footnotetext{
${ }^{2}$ According to the Journal Citation Report (JCR) the most renowned journals in the entrepreneurship field are Journal of Business Venturing, Entrepreneurship Theory and Practice, International Small Business Journal, Journal of Small Business Management, Small Business Economics, and Entrepreneurship and Regional Development. This corroborates our decision to include in our dataset the relevant papers published in these academic journals.
}

Concerning the criteria of selection, we decided to first focus on papers that empirically ${ }^{3}$ covered the entrepreneurial process in diverse contexts (Fig. 1). Abstracts were reviewed and categorised by two independent investigators; and in the case of any doubt, a third investigator made the final selection decision. Based on this criterion, we selected 324 publications as empirical studies of the entrepreneurial process. Second, a new round of reviews was developed to confirm the role of environmental/institutional/contextual variables as barriers or drivers across the entrepreneurial process. At this stage, we distributed the 324 publications so that each paper was read in its entirety by one investigator to classify it according to its importance in this study. When doubts arose, a second investigator read the whole paper and made the selection decision. Finally, we selected 67 empirical papers that explored the role of context in the entrepreneurial process.

\subsection{Data analysis}

During the data analysis, three criteria were applied in order to classify the 67 manuscripts selected. The first criterion used to distinguish papers focused on the developmental stages of the entrepreneurial process: potential entrepreneur, nascent/new entrepreneur, and established/consolidated entrepreneur (Reynolds and White 1997; DeTienne 2010). Several papers addressed more than one stage in the process. Therefore, these papers were considered in various stages. The second

\footnotetext{
${ }^{3}$ We selected empirical papers as a mechanism of internal validity that the effect of environmental conditions was corroborated by doing a robust and tested empirical analysis. We only included one literature review (Miner et al. 2012) of empirical papers on the role of the university environment in the first stage of the entrepreneurial process to help us to understanding previous patterns. We did not include in this analysis reports produced by multi-national organisations to reduce the complexity of our analysis. However, this limitation opens a future research line for exploring the link between diversity in entrepreneurship and in contexts under the stakeholder/policymaker perspective.
} 
criterion related to the inherent diversity in entrepreneurship (i.e. self-employed, traditional entrepreneur, owner demographic entrepreneurs, academic entrepreneur, graduate entrepreneur, and innovative entrepreneur) (Welter 2011). It also helped to distinguish the Schumpeterian orientation per type of entrepreneurial activity (i.e. technology/innovative vs. non-technology/ innovative) (Dencker et al. 2019). The third criterion related to diversity in context. Based on research settings, the manuscripts were grouped into categories of a developed country, a developing country, or as covering multiple countries (as a whole group or explicitly compared contexts) (United Nations 2017). In this step, the positive/negative influences of environmental conditions were identified per entrepreneurship stage, type of entrepreneurship, and type of country. These environmental conditions were subsequently categorised following the elements of entrepreneurial ecosystems, such as policies, support programs, funding, culture, professional infrastructure, university support, labour market, R\&D, and market dynamics. The findings thereof are analysed in the next section.

\section{Findings}

4.1 Diversity in definitions and measures of entrepreneurship

Table 1 shows the operational definitions used by researchers to understand the entrepreneurship phenomenon in the past 15 years.

\subsubsection{Operationalisation of potential entrepreneurship}

For conceptualising potential entrepreneurs, we identified four definitions. A first group of studies defined potential adult entrepreneurs who intend to pursue an entrepreneurial career (Rotefoss and Kolvereid 2005), individuals who are ready to take advantage of opportunities (Shakhovskaya and Akimova 2013), or individuals who have their own reasons for becoming selfemployed (Gohmann 2012). A second group of studies operationalised potential owner demographic entrepreneurship who either expect to set up ventures in deprived regions in the UK (Williams and Huggins 2013) or, as rural women, are exploring venture creation in Bangladesh (Mair and Marti 2007). A third group of studies defined potential graduate entrepreneurs who are students setting up a business (Lebusa 2014; Popescu et al. 2016), who have proficiency in setting up a business (Meintjes et al. 2015), or who are simply considering the possibility of setting up a business (Degeorge and Fayolle 2011). A latter group of manuscripts measured potential academic entrepreneurs who are individuals launching a spin-off based on a recognised opportunity within the university context (Hannibal et al. 2016).

Methodologically, diverse primary sources of information (single/multiple case studies, designed surveys) and secondary sources of information (Eurobarometer, Global Entrepreneurship Monitor, Panel Studies of Entrepreneurial Dynamics, country policy datasets) were employed to analyse the phenomenon of potential entrepreneurship.

\subsubsection{Operationalisation of nascent/new entrepreneurship}

For theorizing nascent/new entrepreneurs, we found four definitions. The first definition was employed to study owner demographic entrepreneurship in terms of the new ventures created: (a) by women business owners (Mair and Marti 2007; Guzmán and Rodríguez 2008); (b) in rural/deprived areas (Atherton and Hannon 2006; Williams and Huggins 2013); (c) according to the rate of business owned by the skilled black community (Bates 2015); or (d) in terms of the new start-up rate of ventures in the social service sector (Gawel and Toikko 2014).

The second definition was adopted to operationalise traditional nascent/new ventures using as follows: (a) the number of youngest start-ups with fewer than 100 employees (Lutz et al. 2010) and the period required to start up a business (Misra et al. 2014); (b) the percentage of the adult population of a country who is involved in the development/creation of entrepreneurial initiatives motivated by necessity or opportunity (Pinillos and Reyes 2011; Shakhovskaya and Akimova 2013); (c) the business demography (entry/exit rates) in diverse industries (Meek et al. 2010; García-Posada and MoraSanguinetti 2015); (d) business owners during the starting phase (Bitzenis and Nito 2005; Edoho 2015; McEwan 2015); and (e) those that were intending to start a new venture, had previously carried out at least one start-up activity, expected to own part of the venture, and did not have an existing operational business (Davidsson and Henrekson 2002; Davidsson and 
Table 1 Diversity in definitions and measurement per entrepreneurial stage

Definitions Stage 1: potential entrepreneur Stage 2: nascent/new entrepreneur Stage 3: established/consolidated

$\begin{array}{cc}{[+]} & \text { IE: innovative } \\ \text { Innova- } & \text { entrepreneur- } \\ \text { tion [-] } & \text { ship }\end{array}$

AE: academic entrepreneurship

\footnotetext{
GE: graduate $\quad$ The trigger is the moment when entrepreneur- the students start thinking ship seriously about setting up a business and devoting
}

- Incubators that assist young technological small- (fewer than 50 employees) and medium-sized enterprises (up to 250 employees) in initial stages-Case study (Abetti 2004)

- New technological organisations incubated - case study (Karlsson et al. 2005)

- Percentage of self-employed that have created knowledge-based innovative firms - OECD, Global Competitive Index (Acs et al. 2009; Szabo and Herman 2014)

- Comparing: self-employment rate (Knightian sense) vs. innovative (patents granted by the country of origin) - panel data (El-Harbi and Anderson 2010)

- New technological ventures created by corporate or independent entrepreneurs - case study (Zahra and Nambisan 2012*)

- Young companies (less than three years old) mostly involved in the product-market fit phase - Case study (Wallin et al. 2016*)

- Academic scientists involved in the commercialisation of activities via university spin-offs - ethnography, panel data (Pilegaard et al. 2010; González-Pernía et al. 2013; Beraza-Garmendia and Rodríguez-Castellanos 2015; Rodríguez-Gulías et al. 2016)

- Nascent university spin-off ventures during the earliest phase of the entrepreneurial process - case study (Rasmussen and Borch 2010; Hannibal et al. 2016*)

- Technology-based ventures that started within the university incubator in the last 3 years - case study (Patton 2014)
- Independent and established firms with at least 20 employees and company groups in technological sectors - comparisons per country and institution (Davidsson and Henrekson 2002)

- From small/young firms to the old/significant firms involved in the IT sector - panel data (Johansson 2004)

- Established technological firms in different sectors - case study (Cooper and Park 2008)

- Well-established innovative firms (Zahra and Nambisan $2012 *)$

- Companies over 3 years old enrolled in the scaling phase - case study (Wallin et al. 2016*) 
Table 1 (continued)

Definitions Stage 1: potential entrepreneur Stage 2: nascent/new entrepreneur Stage 3: established/consolidated

time/resources (Degeorge and

Fayolle 2011)

- Students' intention to create a business - survey (Lebusa 2014; Popescu et al. 2016)

- Entrepreneurial proficiency in school learners - mixed methods (Meintjes et al. 2015)

ODE: owner demographic entrepreneurship
- Any self-supporting activities for rural women across the entrepreneurial process - case study (Mair and Marti 2007*)

- Individuals who expect to set up a venture in a deprived community in the future-Mixed methods (Williams and Huggins 2013*)
- New ventures listed in a rural area of the country directory - case study (Atherton and Hannon 2006)

- Any self-supporting activities by rural women across the entrepreneurial process - case study (Mair and Marti 2007*)

- Opportunities faced by women business owners during the creation of their business - case study (Guzmán and Rodríguez 2008*)

- Individuals who are creating a venture in a deprived community - mixed methods (Williams and Huggins 2013*)

- New start-up rate of companies in the social service sector or tourism sector - case study (Gawel and Toikko 2014; Schiopu et al. 2015)

- Rate of business ownership by highly educated and skilled black community - US Census (Bates 2015)
EN: general entrepreneurship
- Individuals who intend to pursue an entrepreneurial career - survey (Rotefoss and Kolvereid 2005)

- Individuals ready to develop an entrepreneurial activity - GEM intentions (Shakhovskaya and Akimova 2013*)
- Any self-supporting activities of rural women-owned firms across the entrepreneurial process - case study (Mair and Marti 2007)

- Opportunities faced by women business owners during the development of their business - case study (Guzmán and Rodríguez 2008*)

- Micro-, small-, and medium-sized enterprises (MSMEs) owned by a woman who employs fewer than 75 employees - survey (Kairiza et al. 2017)

- Active entrepreneurs of small firms who are first-/second-generation immigrants - mixed methods (Rusinovic 2008)

- Owners operating small businesses in ethnic communities (fewer than 50 employees) - multiple case study (Wang and Altinay 2010)

- Manufacturing senior firms owned by a woman whose initial investment is less than 10 million Indian rupees - Census (Coad and Pawan Tamvada 2012)

- Small firms run by people living in a deprived area - Mixed methods (Williams and Huggins 2013*)

- Small firms run by immigrants registered in the Chambers of Commerce - Panel data (Falavigna et al. 2017)

- Established small- and medium-sized entrepreneurship — panel data (Bateman 2000; Jabani Mambula 2004; Kang and Heshmati 2008; Puffer et al. 2010; Canton et al. 2013; Zhang 2015; Edoho 2015*; 
Table 1 (continued)

\begin{tabular}{|c|c|c|c|}
\hline Definitions & Stage 1: potential entrepreneur & Stage 2: nascent/new entrepreneur & Stage 3: established/consolidated \\
\hline & $\begin{array}{l}\text { - Entrepreneurship as the } \\
\text { exploitation of } \\
\text { opportunities-discourse } \\
\text { analysis (Heinonen and Hytti } \\
\text { 2016) }\end{array}$ & $\begin{array}{l}\text { industries - survey (Lutz et al. } \\
\text { 2010; Edoho 2015*) } \\
\text { - New firm entry rates in the solar } \\
\text { energy industry_-panel data } \\
\text { (Meek et al. 2010; } \\
\text { García-Posada and } \\
\text { Mora-Sanguinetti } 2015^{*} \text { ) } \\
\text { - Percentage of the adult } \\
\text { population (18-64 years old) } \\
\text { involved an entrepreneurial } \\
\text { activity less than } 42 \text { months } \\
\text { old-GEM TEA (Pinillos and } \\
\text { Reyes 2011; Shakhovskaya and } \\
\text { Akimova 2013*) } \\
\text { - The time required for an } \\
\text { entrepreneur to start up a } \\
\text { business (ranges from } 7 \text { to } \\
\text { 72 days)-panel data (Misra } \\
\text { et al. 2014) } \\
\text { - New business activity - Survey } \\
\text { (McEwan 2015) } \\
\text { - Nascent firms - PSED Survey } \\
\text { (Davidsson and Henrekson } \\
\text { 2002; Davidsson and Gordon } \\
\text { 2016; Rotefoss and Kolvereid } \\
\text { 2005; Edelman and Yli-Renko } \\
\text { 2010; Frid et al. 2016) }\end{array}$ & $\begin{array}{l}\text { Hassink et al. 2016; Gupta } \\
\text { 2016; Elston et al. 2016) } \\
\text { • Business owners of firms more } \\
\text { than } 42 \text { months old - GEM } \\
\text { established ventures (Aidis } \\
\text { et al. 2008; Shakhovskaya and } \\
\text { Akimova 2013*) } \\
\text { - Established exporter firms from } \\
\text { emerging economies-probit } \\
\text { (LiPuma et al. 2013) } \\
\text { - Entry and exit rates for corporate } \\
\text { ventures-SABI } \\
\text { (García-Posada and } \\
\text { Mora-Sanguinetti 2015*) } \\
\text { - High-growth firm (HGF) defined } \\
\text { as an employment increment of } \\
10 \% \text { over the last } \\
3 \text { years-panel data (Krasniqi } \\
\text { and Desai 2016) }\end{array}$ \\
\hline $\begin{array}{l}\text { SE: } \\
\text { self-- } \\
\text { employment }\end{array}$ & $\begin{array}{l}\text { - Latent entrepreneurship such as } \\
\text { preferring to be } \\
\text { self-employed-Flash } \\
\text { Eurobarometer (Gohmann } \\
\text { 2012) }\end{array}$ & & $\begin{array}{l}\text { - Self-employment as a measure of } \\
\text { metropolitan } \\
\text { entrepreneurship_US Census } \\
\text { (Coomes et al. 2013) }\end{array}$ \\
\hline
\end{tabular}

*A paper that covers two or three stages. Source: the authors

Gordon 2016; Rotefoss and Kolvereid 2005; Edelman and Yli-Renko 2010; Gartner and Liao 2012; Hopp 2015; Frid et al. 2016)

The third definition measured the phenomenon of academic entrepreneurship through the number of the following: (a) university spin-off ventures during their initial phase of the entrepreneurial process (Rasmussen and Borch 2010; Hannibal et al. 2016); (b) academic scientists involved in the commercialisation of technology via university spin-offs (Pilegaard et al. 2010; González-Pernía et al. 2013; Beraza-Garmendia and Rodríguez-Castellanos 2015; Rodríguez-Gulías et al. 2016); and (c) technology-based ventures incubated in a university incubator (Patton 2014).

The latter definitions have quantitatively theorised the phenomenon of innovative entrepreneurship by contrasting the percentage of self-employed against knowledge-based innovative firms (Acs et al. 2009; Szabo and Herman 2014) or by contrasting the selfemployment rate against patents and grants per country (El-Harbi and Anderson 2010), and have qualitatively analysed the new technological organisations incubated within incubators (Abetti 2004; Karlsson et al. 2005), existing companies (Zahra and Nambisan 2012), or during the product-market fit phase (Wallin et al. 2016).

Regarding the methodology, diverse primary sources of information (single/multiple case stud(ies), longitudinal case studies, designed surveys with follow-up interviews) and secondary sources of information (Global Entrepreneurship Monitor, Panel Studies of Entrepreneurial Dynamics, the U.S. Bureau Census, World Bank, national judicial datasets, OECD datasets, Global Competitiveness Index) with sophisticated statistical models (multi-level regression analysis, panel data 
analysis, negative binomial regressions, multivariate analysis) were employed to analyse the phenomenon of nascent/new entrepreneurship.

\subsubsection{Operationalisation of established entrepreneurship}

For comprehending established entrepreneurs, we found four definitions. The first definition was related to the phenomenon of non-innovative established ventures defined as follows: (a) the number of small- and mediumsized entrepreneurs (Bateman 2000; Jabani Mambula 2004; Kang and Heshmati 2008; Puffer et al. 2010; Canton et al. 2013; Zhang 2015; Edoho 2015; Hassink et al. 2016; Gupta 2016; Elston et al. 2016); (b) the percentage of business-owner firms that are more than 42 months old (Aidis et al. 2008; Shakhovskaya and Akimova 2013); (c) the established exporter firms from emerging economies (LiPuma et al. 2013); (d) the entry and exit rates for corporate ventures (García-Posada and Mora-Sanguinetti 2015); and (e) self-employment as a measure of metropolitan entrepreneurship in the USA (Coomes et al. 2013).

A second group measured owner demographic entrepreneurship in terms of (a) gender (Mair and Marti 2007; Guzmán and Rodríguez 2008; Coad and Pawan Tamvada 2012; Kairiza et al. 2017); (b) the first/second generation of immigrants (Rusinovic 2008; Falavigna et al. 2017); (c) ethnic communities (Wang and Altinay 2010); and (d) people living in a deprived area (Williams and Huggins 2013).

A third group operationalised innovative established ventures using the comparison between the following: (a) independent and established firms with at least 20 employees enrolled in technological sectors (Davidsson and Henrekson 2002); (b) small/young firms and old/ significant firms involved in the I.T. sector (Johansson 2004); and (c) well-established technological/innovative firms involved in different sectors (Cooper and Park 2008; Zahra and Nambisan 2012) or within their scaling phase (Wallin et al. 2016).

Methodologically, diverse primary sources of information (single/multiple case stud(ies), longitudinal case studies, designed surveys with follow-up interviews) and secondary sources of information (Global Entrepreneurship Monitor, U.S. Bureau Census, European Commission, Chambers of Commerce, World Bank datasets, Central Banks, registers of exporters) with sophisticated statistical models (hierarchical regression, panel data analysis, negative binomial regressions) were employed to analyse the phenomenon of established entrepreneurship.

4.2 Environmental drivers/barriers faced by potential entrepreneurs

Table 2 shows the environmental conditions that act as barriers or drivers for individuals (potential entrepreneurs) who are considering the idea of creating a venture based on the identified opportunities and on the time and resources available.

\subsubsection{Developed economies}

Our findings show a set of conditions with a favourable effect on potential entrepreneurs in the context of developed economies.

Regarding potential entrepreneurs without an innovative orientation, government intervention through policies and support programs has created favourable conditions. In Finland, the emphasis of governmental programs on the identification of entrepreneurial opportunities instead of entrepreneurial exploration reinforced the adult population's perception of entrepreneurship as a professional career (Heinonen and Hytti 2016). The labour market and market dynamism have also created favourable conditions for self-employment. In Norway, the labour market conditions caused by the increment in unemployment rates together with market dynamism created by industrial specialisation triggered the population's proclivity to be self-employed (Rotefoss and Kolvereid 2005). The findings also show that certain public programs in the UK tend to cause a negative perception of their effectiveness by their beneficiaries, and consequently potential entrepreneurs prefer not to seek assistance (Williams and Huggins 2013).

Potential (academic) entrepreneurs with an innovative orientation have been reinforced by professional support. French graduate engineers have participated in multiple networking events with diverse agents of the ecosystem to support their entrepreneurial intentions and behaviour (Degeorge and Fayolle 2011). The role of higher education has transformed the attitudes towards entrepreneurship of the university community (i.e. academics, students, and graduates). In Ireland and Denmark, universities have implemented resources and capabilities to configure a favourable environment for academics to commercialise their research outcomes via patents, licences, and spin-offs (Hannibal et al. 
Table 2 Mapping environmental conditions for potential entrepreneurs

\begin{tabular}{|c|c|c|}
\hline \multirow[t]{2}{*}{ Economies } & \multicolumn{2}{|l|}{ Environmental conditions } \\
\hline & Positive effect & Negative effect \\
\hline $\begin{array}{l}\text { Developed } \\
\text { econo- } \\
\text { mies }\end{array}$ & $\begin{array}{l}\text { Policies } \\
\text { EN: Preferential procurement policies implemented by the } \\
\text { government to support entrepreneurship } \\
\text { Support programs } \\
\text { EN: Greater emphasis on the identification of opportunities, } \\
\text { and not only on exploitation } \\
\text { Professional support } \\
\text { GE: Displacing networking events are drivers of actual } \\
\text { behaviour towards a start-up, but interact with perceptions } \\
\text { Higher education } \\
\text { AE: University capabilities facilitating the venture-formation } \\
\text { process: (1) creating new paths of action, (2) balancing } \\
\text { both academic and commercial interests, and (3) } \\
\text { integrating new resources } \\
\text { Labour market } \\
\text { EN: Increase in unemployment leads more people to consider } \\
\text { entrepreneurship } \\
\text { Market dynamism } \\
\text { EN: A strong local industrial specialisation increases } \\
\text { potential entrepreneurship }\end{array}$ & $\begin{array}{l}\text { Support programs } \\
\text { ODE: Support programs in deprived areas may effectively } \\
\text { discourage entrepreneurship, or at least be ineffective (due } \\
\text { to the perceptions of beneficiaries) } \\
\text { Financial support } \\
\text { ODE: Limited funding and traditionally restricted access to } \\
\text { specific markets are barriers that deter black } \\
\text { entrepreneurship }\end{array}$ \\
\hline $\begin{array}{l}\text { Developing } \\
\text { econo- } \\
\text { mies }\end{array}$ & $\begin{array}{l}\text { Professional support } \\
\text { GE: Specific training on problem recognition and problem } \\
\text { solving } \\
\text { ODE: Collaborative platforms by social entrepreneurs } \\
\text { Individual capacity } \\
\text { GE: Individual traits }\end{array}$ & $\begin{array}{l}\text { Policies } \\
\text { EN: Inefficient/unstable policies/legislation, with frequent } \\
\text { legal and tax changes } \\
\text { Higher education } \\
\text { GE: Lack of or ineffective entrepreneurship education in } \\
\text { society and in universities } \\
\text { Market dynamism } \\
\text { ODE: Lack of market-supporting institutions } \\
\text { GE: Transitional socioeconomic context } \\
\text { Culture } \\
\text { EN: Lack of entrepreneurial culture } \\
\text { ODE: The low reputation of entrepreneurs, an informal } \\
\text { activity, and sociocultural norms that impede participation } \\
\text { in market-based activities }\end{array}$ \\
\hline $\begin{array}{l}\text { Multiple } \\
\text { countries }\end{array}$ & $\begin{array}{l}\text { Market dynamism } \\
\text { SE: Economic freedom increases the preference to be } \\
\text { self-employed, and higher corruption increases the } \\
\text { preference to be self-employed }\end{array}$ & $\begin{array}{l}\text { Market dynamism } \\
\text { SE: Higher corruption decreases the preference to be } \\
\text { self-employed }\end{array}$ \\
\hline
\end{tabular}

Source: the authors

$S E$, self-employed; $O D E$, owner demographic entrepreneurship (rural, youth, gender, immigrant, social); $E N$, entrepreneurship with lower innovative/technological outcomes; $A E$, academic entrepreneurship; $G E$, graduate entrepreneurship; $I E$, innovative entrepreneurship (hightech, knowledge-based, high-growth)

2016). As a result, the academic entrepreneurship phenomenon has considerably increased during the past decade.

\subsubsection{Developing economies}

Our findings show conditions with a positive/negative effect on those potential entrepreneurs without an innovative orientation in developing economies. The positive effect was observed within a group of professionals who supported the development of collaborative platforms to facilitate social entrepreneurship initiatives (Mair and Marti 2007). A set of conditions was also found with a negative effect on potential entrepreneurs without an innovative orientation in developing economies. Inefficient government intervention via ineffective 
policies with emphasis on legal and tax regulations generated a hostile environment for potential entrepreneurs in Russia (Shakhovskaya and Akimova 2013). In Bangladesh, the existence of market barriers does not support the entry of owner demographic groups (rural women) (Mair and Marti 2007). Other barriers include non-favourable perceptions/reputation of entrepreneurs in society (Shakhovskaya and Akimova 2013), and the prevalence of sociocultural norms that reduce the participation of owner demographic groups in economicbased activities (Mair and Marti 2007).

Concerning potential entrepreneurs with an innovative orientation in developing economies, in South Africa, an initiative implemented by a professional group who was training secondary-school students to acquire problem-recognition/problem-solving skills obtained positive outcomes (Meintjes et al. 2015). Inefficient entrepreneurial education programs in higher education organisations for the promotion of job creators have also limited the development of entrepreneurial initiatives by graduate students in South Africa (Lebusa 2014) and Romania (Popescu et al. 2016).

\subsubsection{Multi-country studies}

Multi-country studies also show a set of favourable environmental conditions for the potentially selfemployed. Market conditions, such as a higher score on economic freedom indices and a higher level of corruption, lead people to a higher preference for selfemployment in the USA and Europe (Gohmann 2012).

\subsection{Environmental drivers/barriers faced by nascent/ new entrepreneurs}

Table 3 shows the environmental conditions that act as either barriers or drivers for individuals (nascent/new entrepreneurs) who have created a venture with their available resources and are seeking access to new resources and capabilities to operate in the market.

\subsubsection{Developed economies}

Regarding the drivers faced by nascent owner demographic entrepreneurs, a positive influence from legislative changes for decontrolling certain market limitations was found in Finland (Gawel and Toikko 2014). Furthermore, in the USA, the implementation of preferential procurement has legitimised and increased the presence of black-owned businesses in sectors where these minorities were previously unable to operate (Bates 2015). Moreover, the government implementation of acceleration/incubation programs exerts a positive effect on fostering the gestation of rural entrepreneurial initiatives in deprived regions of the UK (Atherton and Hannon 2006; Schiopu et al. 2015). Regarding the barriers faced by nascent owner demographic entrepreneurs, British policies for fostering owner demographic entrepreneurship in deprived regions have been ineffective due to their failure to consider the nascent entrepreneurs' mind-sets, behaviour, and skills (Williams and Huggins 2013). Other non-favourable conditions include the limited access to public funds, which has restricted the entry of owner demographic groups of entrepreneurs into specific markets in the USA (Bates 2015), and the discriminatory environment, which has limited the participation of black communities in entrepreneurship in the USA (Bates 2015).

Concerning the drivers of nascent entrepreneurship without an innovative orientation, universities have also delivered entrepreneurship-training programs oriented towards reinforcing skills of nascent entrepreneurs (McEwan 2015). The effectiveness of support assistant in the development of business plans has positively influenced to increase formal financial support in Sweden (Honig and Karlsson 2004) and the USA (Yusuf 2010; Hopp 2015). The inefficiency of the Spanish judicial system has represented a barrier for a nascent entrepreneur through setting higher fixed costs that must be paid to diverse agents (García-Posada and MoraSanguinetti 2015). Similarly, a lack of regulation and a lack of funding from public/private sources in the Netherlands (Lutz et al. 2010) or the industrial specialisation in Norway (Rotefoss and Kolvereid 2005) have limited the emergence of nascent entrepreneurship. It can also be observed that specific social norms or wealth inequalities have reduced the effectiveness of policies oriented towards the promotion of nascent entrepreneurship in the USA (Meek et al. 2010; Frid et al. 2016). Indeed, the temporary/permanent entry or adaptation of nascent entrepreneurship is influenced by the response of markets to environmental uncertainty in the USA (Edelman and Yli-Renko 2010; Gartner and Liao 2012) or macroeconomic crises in Australia (Davidsson and Gordon 2016).

Regarding the drivers/barriers faced by nascent academic entrepreneurship, professional support has reinforced academic entrepreneurs with business contacts, mentors, and facilitators during the conception of their 
Table 3 Mapping environmental conditions for nascent/new entrepreneurs

Economies Environmental conditions

$\begin{array}{ll}\text { Positive effect } \quad \text { Negative effect } & \end{array}$

\begin{tabular}{|c|c|c|}
\hline $\begin{array}{l}\text { Developing } \\
\text { econo- } \\
\text { mies }\end{array}$ & 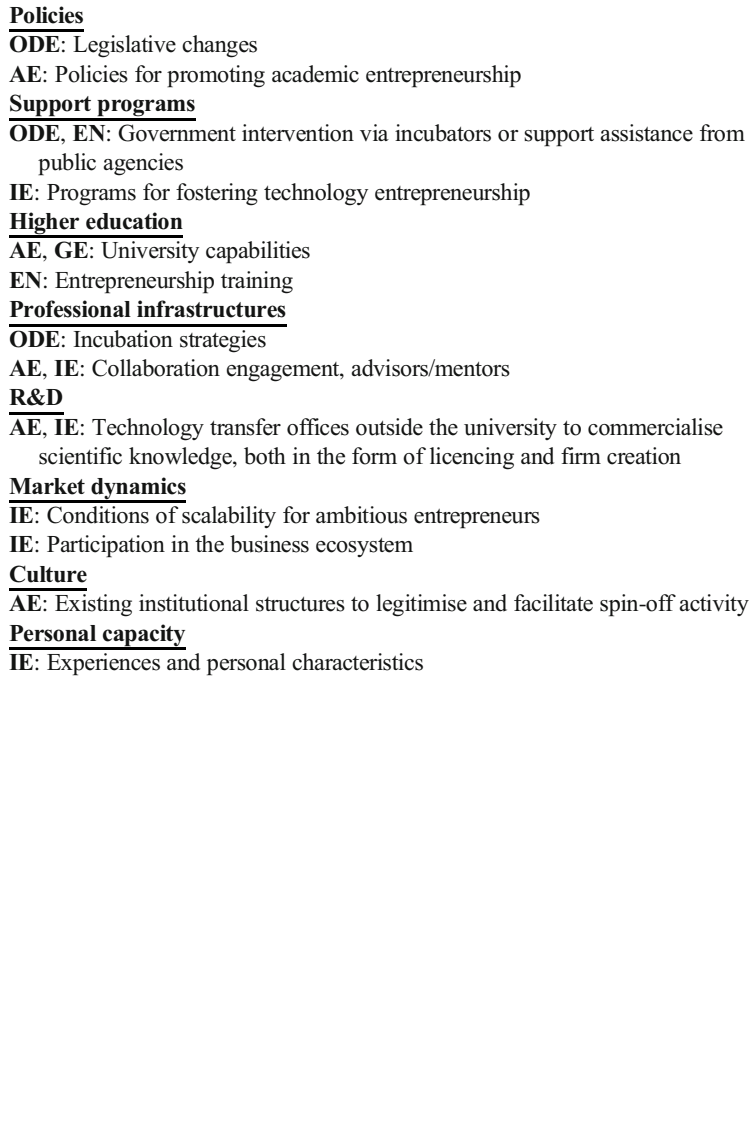 & $\begin{array}{l}\text { Policies } \\
\text { EN: The judicial (in)efficacy for new entrepreneurs but not for } \\
\text { corporate entrepreneurs, industrial specialisation policies } \\
\text { GE: Government rules and regulations for graduate entrepreneurs } \\
\text { Support programs } \\
\text { ODE: Entrepreneurship support for new entrepreneurs in deprived } \\
\text { communities } \\
\text { Financial support } \\
\text { EN: Significant barriers: access to capital } \\
\text { Market dynamic } \\
\text { IE: Perception of barriers by ambitious entrepreneurs } \\
\text { EN: Access to distribution channels, effects of macroeconomic crises } \\
\text { or uncertainty, munificence } \\
\text { R\&D } \\
\text { EN: Product differentiation, R\&D, and advertising } \\
\text { Culture } \\
\text { EN: Social norms or wealth inequalities affecting new entrepreneurs } \\
\text { ODE: A discriminatory environment, such as a critical barrier that } \\
\text { limits owner demographic entrepreneurs in the USA } \\
\text { IE: Individual perceptions and constraints }\end{array}$ \\
\hline $\begin{array}{l}\text { Multiple } \\
\text { countries }\end{array}$ & $\begin{array}{l}\text { Policies } \\
\text { EN: Start-up procedures, taxation, interest rates } \\
\text { Support programs } \\
\text { ODE, EN: Incubation programs } \\
\text { Market dynamics } \\
\text { IE: Business freedom and corruption increase innovative entrepreneurs } \\
\text { SE: Freedom for foreign investment } \\
\text { Culture } \\
\text { EN: A supportive national culture } \\
\text { Higher education } \\
\text { AE: University support programs for spin-offs } \\
\text { R\&D } \\
\text { IE: Knowledge spillover }\end{array}$ & $\begin{array}{l}\text { Policies } \\
\text { EN: Bureaucracy in registration procedures } \\
\text { Financial support } \\
\text { IE: Risk capital, lack of funds } \\
\text { ODE: Discrimination in accessing bank credit } \\
\text { Professional support } \\
\text { EN: Institutional pressures } \\
\text { Market dynamics } \\
\text { SE: Business freedom and corruption decreases self-employment } \\
\text { Culture } \\
\text { ODE: Discrimination against minority groups } \\
\text { R\&D } \\
\text { IE: Lack of public/private R\&D investment }\end{array}$ \\
\hline
\end{tabular}

Source: the authors

$S E$, self-employed; $O D E$, owner demographic entrepreneurship (rural, youth, gender, immigrant, social); $E N$, entrepreneurship with lower innovative/technological outcomes; $A E$, academic entrepreneurship; $G E$, graduate entrepreneurship; $I E$, innovative entrepreneurship (hightech, knowledge-based, high-growth)

entrepreneurial and innovative initiatives (Pilegaard et al. 2010). In Norway and Denmark, universities have implemented resources and capabilities to configure a favourable environment for academics to commercialise their research outcomes via patents, licences, and spinoffs (Rasmussen and Borch 2010; Hannibal et al. 2016). In Denmark, the specialisation in research activities also represented a driver for academic entrepreneurship over 
several years (Pilegaard et al. 2010). In Norway, Spain, and the UK, university capabilities have positively influenced the commercialisation of knowledge via the creation of spin-offs, licences, and patents by academics and researchers (Rasmussen and Borch 2010; BerazaGarmendia and Rodriguez-Castellanos 2015; Rodríguez-Gulías et al. 2016). The legitimisation of academic entrepreneurship by addressing societal challenges and needs has positively influenced the gestation of new entrepreneurial initiatives by academics and university students in Denmark (Pilegaard et al. 2010).

Focusing on the drivers/barriers faced by nascent innovative entrepreneurs, the government implementation of acceleration/incubation programs exerts a positive effect on fostering the gestation of entrepreneurial innovations in Finland (Abetti 2004) and the UK (Patton 2014). Furthermore, the existence of professional infrastructures has generated a positive effect on nascent entrepreneurship: in particular, the significant role of professional support during the development of collaboration engagements, as well as the support received from advisors and mentors during the gestation of entrepreneurial ideas in the UK context (Patton 2014). Market conditions have also acted as driver and barrier for nascent entrepreneurs in developed economies. The innovative entrepreneurs' involvement within the entrepreneurship ecosystem has produced significant effects by reducing the entry barriers for nascent entrepreneurs (Zahra and Nambisan 2012) and also by scaling business models (Wallin et al. 2016). Culture also plays a crucial role in nascent entrepreneurship regarding the perception of growth and ambitions by entrepreneurs in Finland (Wallin et al. 2016).

\subsubsection{Developing economies}

Our findings in developing economies show only a set of environmental conditions that are limiting nascent entrepreneurs without an innovative orientation. The policies that have negatively affected the gestation of new entrepreneurs include as follows: (a) the uncertainty produced by the multiple changes in business taxation procedures (Bitzenis and Nito 2005); (b) the misalignment and inconsistencies between policies and programs (Edoho 2015); and (c) the lack of precise regulation regarding liquidations and a weak legislative basis for venturing investments (Shakhovskaya and Akimova 2013).
Similarly, the lack of diverse public/private sources of funding for entrepreneurs (Bitzenis and Nito 2005) and the exorbitant interest rates when accessing private funds (Edoho 2015) have represented significant barriers to nascent entrepreneurship. The absence of institutions that support the dynamism of rural markets represents the third set of barriers for owner demographic entrepreneurs in countries such as Bangladesh (Mair and Marti 2007). Finally, sociocultural elements such as corruption and a non-favourable reputation of entrepreneurship have not only limited the gestation of new ventures but also influenced the failure of new ventures in post-Soviet economies, such as Russia (Shakhovskaya and Akimova 2013).

\subsubsection{Multi-country studies}

The findings from multi-country studies show that the effectiveness of governmental support programs (e.g. business incubation) across the globe has facilitated the hazardous gestation of new owner demographic ventures in the area known as the third sector (tourism) (Schiopu et al. 2015). Along the same lines, Guzmán and Rodríguez (2008) find that social discrimination has also limited access to the bank funding of owner demographic groups (women entrepreneurs). Regarding nascent ventures without an innovative orientation, government intervention (e.g. taxation policies and regulations for controlling interest rates) has facilitated venture creation in both developed and developing economies (Misra et al. 2014). Misra et al. (2014) also found that the bureaucracy in the registration procedures has limited new venture creation in developing economies. Complementary, favourable market conditions are useful for the detection of trade opportunities in both developed and developing countries (Misra et al. 2014). Moreover, national culture has supported the gestation of nascent entrepreneurs in countries with a collectivist orientation and has limited this gestation in countries with an individualistic orientation (Pinillos and Reyes 2011).

Concerning academic entrepreneurship, the role of higher education organisations has been shown in multicountry studies in the context of developed economies (e.g. UK, Spain, Denmark, and Ireland). In particular, university policies are suitable for the regulation of the creation of spin-off support programs (BerazaGarmendia and Rodríguez-Castellanos 2015), and university infrastructure (incubators or technology transfer 
offices) can help during the identification of opportunities and spin-off creation (Hannibal et al. 2016).

Regarding innovative nascent ventures, El-Harbi and Anderson (2010) found that certain market conditions, such as business freedom and perception of corruption, increase innovative entrepreneurship but decrease selfemployment across the OECD economies. By contrasting the professional support offered by incubators, Karlsson et al. (2005) find that a negative effect on business creation is due to the pressure to access venture capital in certain economies (Israel). Furthermore, lower investments in $\mathrm{R} \& \mathrm{D}$, together with lower risk capital provided by public and private agents, have limited the gestation of innovative and productive initiatives in transition economies (Szabo and Herman 2014).

\subsection{Environmental drivers/barriers faced by established/ consolidated entrepreneurs}

Table 4 shows the environmental conditions that act as barriers or drivers for individuals (established/consolidated entrepreneurs) who have created and/or managed a venture that has operated in the market for several years.

\subsubsection{Developed economies}

The findings show insights into the environmental conditions that have influenced the consolidation of diverse types of ventures in developed economies.

Regarding consolidated owner demographic entrepreneurship, the implementation of regulations for immigration and the excellent functioning of the Italian judicial system have contributed towards the consolidation of ventures created by immigrants (Falavigna et al. 2017). Furthermore, the configuration of business/ family networks has created favourable conditions for the consolidation process of ethnic and immigrant entrepreneurship (Rusinovic 2008; Wang and Altinay 2010). Despite these favourable conditions, it can also be observed how the inefficiency in the follow-up of intervention programs in deprived rural regions in the UK has restricted venture growth (Williams and Huggins 2013). As for well-established ventures without an innovative orientation, the regulations and efficiency of the Spanish judicial system have nurtured the transition of incubated ventures towards a consolidated stage in terms of size and growth (García-Posada and Mora-Sanguinetti 2015). The higher income-tax rates and the minimum wage have negatively influenced the consolidation of ventures created by the self-employed (Coomes et al. 2013).

Regarding well-established innovative ventures, the implementation of public incubation/acceleration programs in Finland (Wallin et al. 2016) and incentives for wealth accumulation in Sweden (Davidsson and Henrekson 2002) have supported the consolidation of ventures with technological and high-growth orientation. The available public/private financial support was focused on business growth (Davidsson and Henrekson 2002). Similarly, the credit guarantee based on achieving better performance (Kang and Heshmati 2008) has significantly influenced the consolidation of innovative ventures. Nevertheless, a large and highly centralised public sector, with a high level of taxes, discourages Swedish entrepreneurs in certain sectors, such as services (Johansson 2004). Indeed, the increment of income tax together with high labour costs has negatively affected high-growth ventures in Sweden (Davidsson and Henrekson 2002).

\subsubsection{Developing economies}

Regarding well-established owner demographic entrepreneurship, the most favourable conditions in the consolidation of rural and social ventures created by Bangladeshi women have been their networking and participation in collaboration platforms (Mair and Marti 2007). The obstacles in the consolidation of ventures include a lack of legitimisation and the low reputation of entrepreneurs (Coad and Pawan Tamvada 2012). For well-established entrepreneurship without an innovative orientation, the most favourable conditions have been the informal sources of funding - such as personal savings, family, and friends - in the consolidation of micro ventures in China (Elston et al. 2016) and the credit guarantee that supported the consolidation in Korea (Kang and Heshmati 2008). Competitive intensity has positively influenced the consolidation of small- and medium-sized ventures in India (Gupta 2016).

On the other hand, the obstacles in the consolidation of ventures are related to (a) a lack of financial sources (Jabani Mambula 2004); (b) a lack of appropriate policies/taxation that supports the consolidation of ventures (Edoho 2015); (c) inadequate and misaligned support programs implemented by governments (Edoho 2015); (d) entry barriers to the market (Shakhovskaya 
Table 4 Mapping environmental conditions for established/consolidated entrepreneurs

Economies Environmental conditions

Positive effect Negative effect

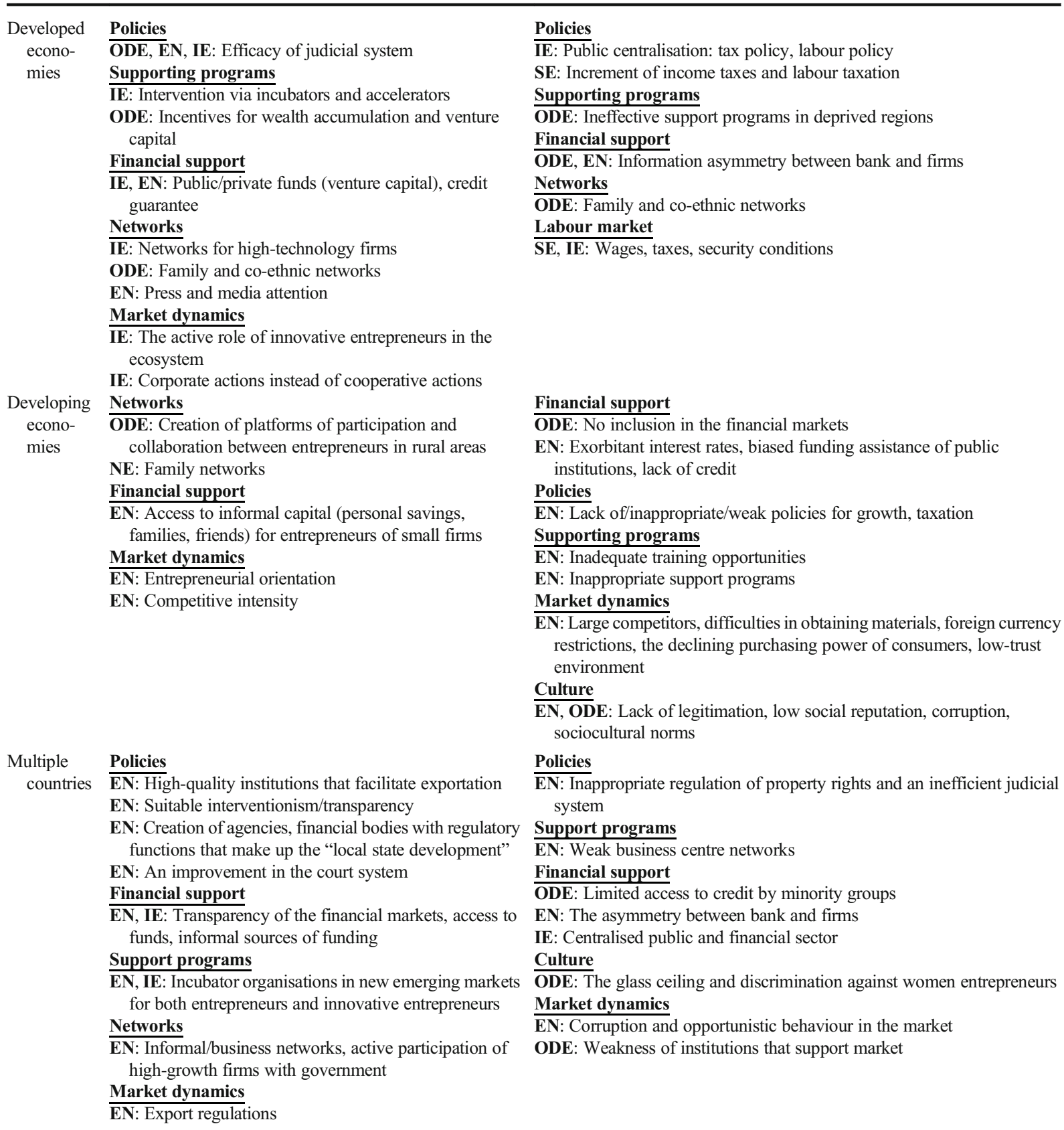

Source: the authors

$S E$, self-employed; $O D E$, owner demographic entrepreneurship (rural, youth, gender, immigrant, social); $E N$, entrepreneurship with lower innovative/technological outcomes; $A E$, academic entrepreneurship; $G E$, graduate entrepreneurship; $I E$, innovative entrepreneurship (hightech, knowledge-based, high-growth) 
and Akimova 2013); and (e) the low-trust environment that limits enterprise growth (Zhang 2015).

\subsubsection{Multi-country studies}

Multi-country studies also show conditions that have influenced the consolidation of diverse types of ventures. Concerning established owner demographic entrepreneurship, the limited access to credit by owner demographic groups and asymmetry of information have conditioned the growth of owner demographic entrepreneurship (Guzmán and Rodríguez 2008). This type of entrepreneurship is also associated with cultural elements such as discrimination and opportunistic behaviour in society.

For well-established ventures without an innovative orientation, we identified the role of suitable government intervention through tax/exporter regulations that have contributed towards local development by supporting the consolidation of export-oriented ventures (LiPuma et al. 2013). In this vein, Puffer et al. (2010) highlighted a lack of the proper regulation of property rights and of the judicial system that reduce the consolidation of innovative entrepreneurship. The least effective programs were those that imitate business support centres that are financially unsustainable in transition economies (Bateman 2000). Moreover, the asymmetry of financial information limited the growth of ventures in the European Union (Canton et al. 2013). Aidis et al. (2008) found that informal business networks have contributed to the consolidation of ventures without a strong innovative orientation in transitional economies.

Concerning well-established innovative ventures, the most effective program has been the establishment of business incubators to support innovative entrepreneurs in developed economies (Cooper and Park 2008).

\section{Discussion and future directions}

\subsection{Discussion}

Our findings aggregate insights in the research published on diversity in entrepreneurship (types of entrepreneurship per stage) and context (environmental conditions per developed/developing economies) over the past two decades (Table 5).

First, regarding the type of entrepreneurship, the results confirm the existence of diversity in the definitions and measurement of entrepreneurship. According to Iversen et al. (2007), entrepreneurship is considered a multifaceted concept with diverse conceptual definitions (Schumpeter, Knight, Kirzner, Schultz) and empirical measures (self-employment rates, business ownership rates, entry/exit rates, total entrepreneurial activity) that have been illustrated in a cross-country comparison. Our research extends previous studies by analysing the diversity in entrepreneurship as a process and the diversity of conditions in fostering/impeding the development of entrepreneurial and innovative activities. According to Schumpeter's ideas (1934), the entrepreneur is an agent of change who carries out innovations/technologies that push the economy towards a new equilibrium.

In this regard, the most favourable conditions of the ecosystem for Schumpeterian entrepreneurship (academic, graduate, and innovative) include public subsidy/incentive programs, support of professional mentors, incubators/accelerators, the universities' orientation towards entrepreneurship (educational programs, transforming attitudes of the university community, connecting research with social demands), collaboration with multiple public/private agents (networking), and public/private R\&D investment. Similarly, less favourable conditions include the lack of private/public funding sources, labour market conditions, and social norms. If we analyse entrepreneurs without an innovative orientation, within the period of analysis, the research published shows mixed patterns but mostly presents adverse effects of environmental conditions on entrepreneurial stages of non-Schumpeterian entrepreneurship (self-employment, owner demographic groups, and traditional entrepreneurship). Notably, environmental conditions - such as regulations/programs, support infrastructures, networks, and market dynamicsillustrate a dual effect (positive and negative). The remaining elements of the ecosystem (finance, culture, R\&D, higher education) exhibit negative effects. A plausible explanation should be the nature of this type of entrepreneur, who is mainly motivated by the need to survive instead of by the identification of business opportunities (Dencker et al. 2019).

Second, regarding the type of entrepreneurial stage, the results show diversity in the entrepreneurial process. The majority of published research focuses on the study of the conditions that have influenced the gestation of nascent/new ventures in diverse contexts (academic entrepreneurship, innovative entrepreneurship, traditional 
Table 5 Entrepreneurship and environmental conditions per economic stage

Potential entrepreneurship

Environmental conditions Non-Schumpeterian

Developing (India, Russia)

SE ODE EN

Policy

Programs

Financial support

Culture

Professional support

Infrastructures

Higher education

Labour market

Networks

Market dynamics

R\&D

Individual capabilities

Nascent/new entrepreneurship

Environmental conditions Non-Schumpeterian

Developing (Albania, Russia, African countries)

SE ODE EN

Policy

Programs

Financial support

Culture

Professional support

Infrastructures

Higher education

Labour market

Networks

Market dynamics

$\mathrm{R} \& \mathrm{D}$

Individual capabilities

Established entrepreneurship

Environmental conditions Non-Schumpeterian

Developing (India, China, Nigeria, Russia, Zimbabwe, western/central Europe, transition economies)

SE ODE EN

Policy

Programs

Financial support

Culture
Developed (Finland,
Netherlands, Spain
UK, USA, OECD)

Developed (Finland,
Netherlands, Spain,
UK, USA, OECD)

Developed (Finland,
Netherlands, Spain,
UK, USA, OECD)

\section{Developed (Norway, Finland, UK)}

SE ODE EN

$\pm$

SE

ODE EN

$\pm$

$\pm$

$\pm \quad-$

$-\quad \pm$

$\begin{array}{rr} & + \\ & \\ & \\ \pm & -\end{array}$

Schumpeterian
Developing
(Romania, South Africa)
Developed (USA,
France, Denmark, Ireland)

GE AE IE GE AE IE

$+$

$+$

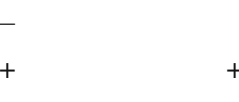

Schumpeterian

Developing

Developed (Denmark, Ireland, Finland, Norway, Spain, UK, USA)

GE AE IE GE AE IE

Schumpeterian

Developed (Italy, Korea, Developing Developed (Canada, Netherlands Spain, USA, UK, European countries)

SE ODE EN $+\quad+\quad+$

$+$

$-$

$\pm$
Finland, Sweden, Italy, UK, USA)

GE AE IE GE AE IE 
Table 5 (continued)

Professional support

Infrastructures

Higher education

Labour market

Networks

Market dynamics

$\mathrm{R} \& \mathrm{D}$

Individual capabilities

Source: the authors

$(+)$ positive effect, $(-)$ negative effect, $( \pm$ ) mixed effect; $S E$, self-employed; $O D E$, owner demographic entrepreneurship; $E N$, entrepreneurship with lower innovative/technological outcomes; $A E$, academic entrepreneurship; $G E$, graduate entrepreneurship; $I E$, innovative entrepreneurship (high-tech, knowledge-based, high-growth)

entrepreneurship, owner demographic entrepreneurship). A limited number of studies have studied the transition of a new venture towards a consolidated/ established venture in both innovative and noninnovative types of entrepreneurship. One plausible explanation indicates the lack of available longitudinal information that would otherwise enable a better understanding of the evolutionary process of ventures. ${ }^{4} \mathrm{Sim}-$ ilarly, a few studies have analysed the survival/ consolidation of university spin-offs or technologybased entrepreneurship with several limitations (Miner et al. 2012). The diversity in entrepreneurship opens a window of scenarios for the exploration of potential entrepreneurs. Within the past two decades, potential entrepreneurship has mainly been studied within the university context (graduate students or academic entrepreneurship) or as an individual career decision (employed vs. self-employed vs. entrepreneurship). However, labour market conditions have been critical conditions in both cases.

Third, regarding the type of economy, the results confirmed diversity in the context. The research settings of studies published on Schumpeterian entrepreneurship involve developed economies (the USA, the UK, Spain, Denmark, Ireland, France, Sweden) and a few transition economies. Therefore, given their nature, there is a concentration of innovative entrepreneurship studies on developed economies. The research settings of studies published on non-innovative entrepreneurship include developed economies (the USA, the UK, Finland, Netherlands, Norway) and developing economies (Romania, India, Albania, Russia, Bangladesh, South

\footnotetext{
${ }^{4}$ An alternative way to study the transition of nascent towards new entrepreneurship could be tried by using the Panel Studies of Entrepreneurial Dynamics. For further details, visit http://www.psed.isr. umich.edu/psed/home
}

Africa, Nigeria). Therefore, both trends highlight the need to clarify the diversity in entrepreneurship and the diversity in contextual conditions in terms of region, country, or multiple countries. Furthermore, it is crucial to understand the evolutionary stages of ecosystems in both developed and developing countries. Our findings reveal several uncertain patterns regarding the following: (a) the dual positive/negative effects of government intervention through policies and programs; (b) the configuration of formal/informal relationships within the financial system; and (c) the social legitimisation of diversity in entrepreneurship that conditions the transition from one stage to another.

\subsection{Research agenda}

Reviews play a critical role in the accumulation of knowledge in entrepreneurship by providing unique contributions towards theory testing, theory development, the identification of research gaps, and suggestions for future research (Rauch 2019). In this regard, Fig. 2 shows the contribution of this study to the field and proposes a research agenda regarding diversity in entrepreneurship, entrepreneurial process, and context based on the identified strengths/weaknesses.

First, the current conceptualisation and measurement of entrepreneurship should be reviewed (Dencker et al. 2019; Henrekson and Sanandaji 2019). Indeed, future research demands the re-conceptualisation of entrepreneurship given the social reconfiguration (diversified workforce, such as multiple-age generations; the mobilisation of people, such as during migration and refugee placement; and democratisation and political movements), new economic models (digital economy, green economy), and technological transformation (big data, digital platforms, artefacts). 


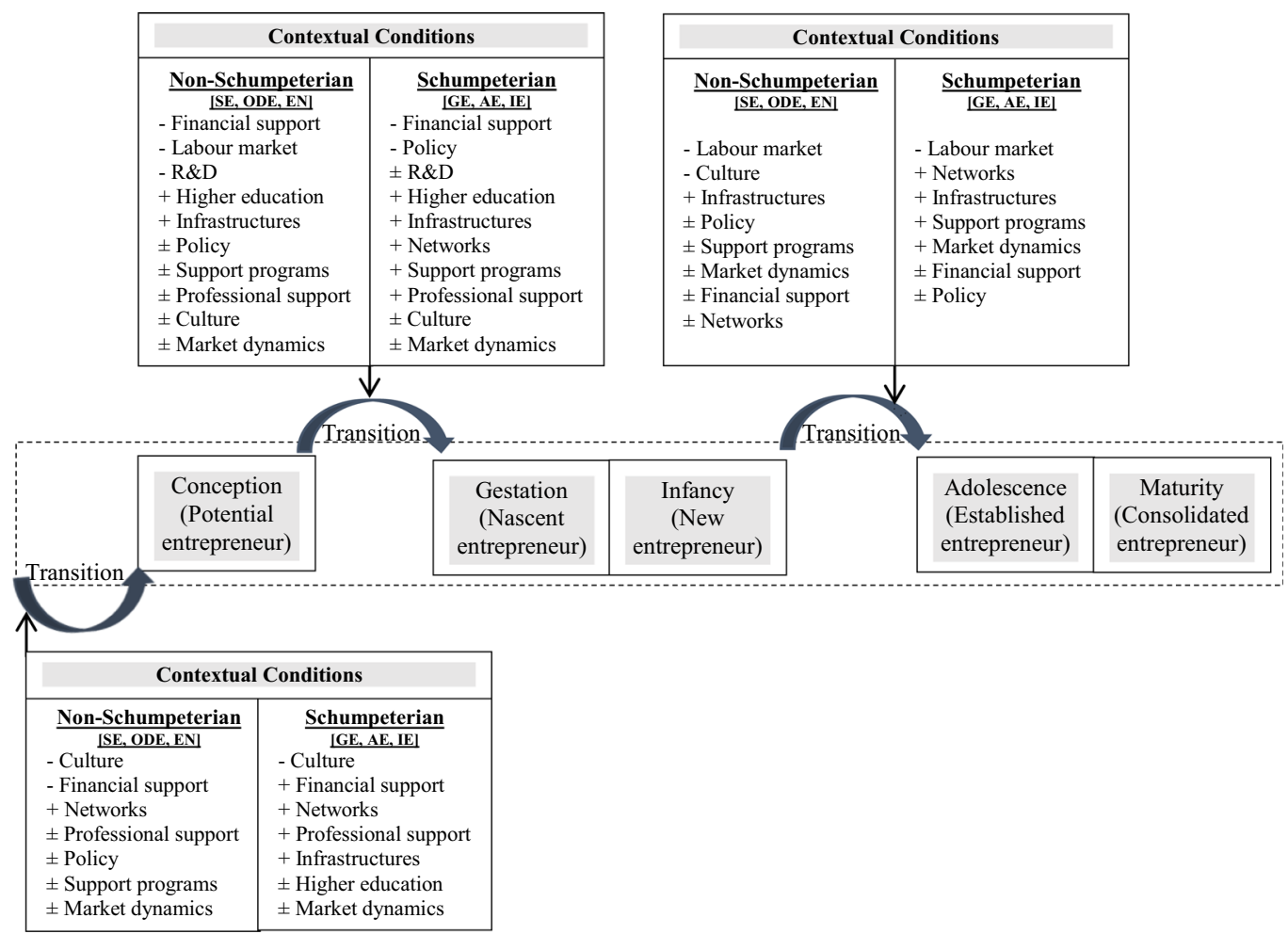

Note 1: Non-Schumpeterian entrepreneurs ( $\mathrm{SE}=$ Self-employed; ODE=Owner demographic entrepreneurship; EN= Entrepreneurship with lower innovative/technological outcomes) and Schumpeterian entrepreneurs ( $\mathrm{GE}=$ Graduate entrepreneurship; $\mathrm{AE}=\mathrm{Academic}$ entrepreneurship; IE= Innovative entrepreneurship (high-tech, knowledge-based, high-growth))

Note 2: $(+)$ positive effect, $(-)$ negative effect, $( \pm)$ mixed effect identified in the literature

Note 3: Adopting the institutional economics approach: formal conditions (policy, programs, financial support, professional support, infrastructures, higher education, labour market, and R\&D) and informal conditions (culture, perceptions)

Fig. 2 Entrepreneurial process influenced by contextual conditions.

Second, future research demands a dynamic analysis that includes the role of time, space, and context across the entrepreneurial process. The lack of studies on environmental conditions and potential entrepreneurship opens a window for the development of research in this stage (e.g. narratives, ethnographies, experiments). In the same vein, research avenues may be pointed out in the transition of nascent/new ventures towards established/consolidated ventures (e.g. longitudinal studies; cross-country studies with emphasis on transition economies). This also implies the opportunity for theory development that adopts mixed theoretical approaches (e.g. institutional theory, spillover theory, evolutionary approaches). Indeed, those largely ignored stages in the traditional entrepreneurial process (i.e. intrapreneurship and exit/failure events) should also be included in future analysis (Guerrero and PeñaLegazkue 2019; Guerrero and Espinoza-Benavides 2020).

Third, the diversity in contexts should be explored by considering the direct, indirect, mediation, and moderation role of the elements of the ecosystem. Researchers should also consider the time/space relation in the analysis of entrepreneurial ecosystems (i.e. the evolution of the ecosystem). Therefore, the interactive influence of both formal (regulations, programs) and informal (culture, perceptions, social norms) environmental conditions should be thoroughly explored in the transition from one entrepreneurial stage to another, as well as in terms of the type of economy (Eesley et al. 2018). Time plays a crucial role in the (re) configuration of entrepreneurial ecosystems in challenging or stimulating environments. Another research venue may be pointed out in how economic crises and natural disasters can bring deep and sudden changes in entrepreneurship. Moreover, our analysis likewise shows the lack of studies that explore the configuration and the effect of environmental conditions in the digital context (Nambisan et al. 2019). 
Fourth, our findings are non-conclusive regarding government intervention via policies and programs for fostering technology throughout the entrepreneurial process. Therefore, it is necessary to seek the evaluation of the impacts of public technological policies that foster entrepreneurship across the globe (Guerrero and Urbano 2019b). Our results also legitimise the decisive role of higher education entrepreneurial ecosystems, professional supports, and infrastructures in technology entrepreneurship. A detailed exploration is necessary into the public, private, and mixed sources of funds across the entrepreneurial process. On the finance side, there is a need to understand the real effects of taxes and labour market costs on the dynamic transition from one entrepreneurial stage to the next (Van Stel et al. 2019). In addition, the role of culture in each type of entrepreneurship is crucial for the understanding of the role of behaviour, values, and social norms across countries (Audretsch et al. 2019).

Fifth, the lack of studies on developing economies highlights the need for an in-depth analysis into contemporary phenomena, such as high-growth technological entrepreneurship (De Fuentes et al. 2020), technological return migrants (Crowley-Henry et al. 2018; Hofmann 2018), and graduate technological entrepreneurship (Wright et al. 2017; Guerrero and Urbano 2019a). Despite our insights (Fig. 2), it is important to continue exploring how context affects (a) the prevalence of individuals and ventures in the initial or pre-profit stage; (b) new firms with profits for a couple of years; and (c) established new ventures with profits for a couple of years. This implies the analysis of the contextual conditions that influence the success/failure in the transition, the performance of the ventures, and the assessment of the orientation of the growth.

Sixth, future research should also include reports produced by multinational organisations (World Bank, Economic Forum, Global Entrepreneurship Monitor, Panel Study of Entrepreneurial Dynamics, European Commission, Inter-American Development Bank, OECD, among others) and research institutions (Kauffman Foundations, NESTA, Babson College, Global Entrepreneurship Institute, Max Planck Institute, among others) without ignoring the stakeholder approach (Barney and Harrison 2020). In this vein, it is crucial to analyse the influence of diversity in contextual conditions per entrepreneurial stage (see Appendix Table 6), as well as the specific drivers/barriers in the transition from one stage to the next one.
5.3 Implications for entrepreneurs and policymakers

Several implications also emerge from our aggregated findings (Fig. 2). For entrepreneurs in developed economies, our findings reveal that informal networks and ethical relationships with diverse agents from the entrepreneurial ecosystem reduce the entry barriers to the market and facilitate the transition towards the next entrepreneurial stage. Therefore, active participation in the ecosystem by each type of entrepreneur constitutes good practice for sustained evolution and for the entrepreneurs to become agents of change in society.

For entrepreneurs in developing economies, the findings suggest that informal collaborative and funding platforms promoted by entrepreneurs may present an excellent alternative to the reduction of the effects of institutional voids associated with $R \& D$ and funding sources. Consequently, these initiatives reinforce the entrepreneurial ecosystem but also produce a favourable effect on the performance of ventures and the implementation of innovative business models.

For policymakers, the findings underline the crucial role of funding across the entrepreneurial process. Successful public-private formulae implemented in developed economies could prove to be good practices in developing economies: in particular, regarding financial market regulations, bankruptcy regulations, and regulations of the venture or business angels' networks. Moreover, in developing economies, policymakers should design strategies for the configuration and reinforcement of their entrepreneurial ecosystems based on their business structure, without imitating existing models (Audretsch 2019).

From an education perspective, the promotion of entrepreneurial competences and an entrepreneurial mind-set at the different levels of the education system (Nabi et al. 2018) are undoubtedly relevant for both innovative and non-innovative entrepreneurship. A further implication is associated with diversity in entrepreneurship and the efficient use of public resources, which encourage the various stages of the entrepreneurial process. In this case, an alternative is given by the co-creation process and commitment among the agents involved in the innovation and entrepreneurial ecosystems.

\section{Conclusions}

This paper analysed the environmental conditions that have influenced the entrepreneurial processes in both developed 
and developing economies. By reviewing the literature from 2000 to 2017, we conclude that the most favourable ecosystem conditions across the entrepreneurial process have been professional support, incubators/accelerators, networking with multiple agents, and R\&D investments. As well, the less favourable ecosystem conditions across the entrepreneurial process have been the lack of funding sources, labour market conditions, and social norms.

Our paper contributes towards academic debates in the field: (a) the debate regarding the entrepreneurial process (Busenitz et al. 2014) and operational definitions of entrepreneurship (Iversen et al. 2007; Henrekson and Sanandaji 2019); (b) the discussion about which elements of entrepreneurial ecosystems are of significance per type of entrepreneurship (Acs et al. 2017; Audretsch 2019); (c) the analysis of the relationship between the diversity of entrepreneurship and context (Welter 2011; Welter et al. 2017; Karlsson et al. 2019); and (d) the relationship between entrepreneurship, environmental conditions, and economic development (Urbano et al. 2019). We hope that our study also inspires researchers to extend the analysis of the reasons why diversity is so crucial for entrepreneurship and societal development.

Funding information The authors received financial support from the Spanish Ministry of Economy \& Competitiveness (Ref.: ECO2016-75655-P).

\section{Appendix}

Table 6 Prevalence rate of entrepreneurial activity and contextual conditions

\begin{tabular}{|c|c|c|c|c|c|c|c|c|}
\hline \multirow[t]{2}{*}{ Economy } & \multirow{2}{*}{$\begin{array}{l}\text { Period of } \\
\text { analysis }\end{array}$} & \multicolumn{4}{|c|}{ Entrepreneurial process } & \multicolumn{3}{|c|}{ Environmental conditions } \\
\hline & & $\begin{array}{l}\text { Entrepreneurial } \\
\text { intentions }\end{array}$ & $\begin{array}{l}\text { Total early-stage } \\
\text { entrepreneurial } \\
\text { activity (TEA) }\end{array}$ & $\begin{array}{l}\text { Established } \\
\text { business } \\
\text { ownership }\end{array}$ & $\begin{array}{l}\text { Entrepreneurial } \\
\text { employee } \\
\text { activity }\end{array}$ & Financing & $\begin{array}{l}\text { Governmental } \\
\text { support and } \\
\text { policies }\end{array}$ & $\begin{array}{l}\text { Taxes and } \\
\text { bureaucracy }\end{array}$ \\
\hline Belgium & $2000-2015$ & 7.26 & 4.12 & 3.57 & 7.05 & 3.15 & 2.90 & 2.10 \\
\hline Canada & $2000-2017$ & 10.38 & 11.70 & 6.68 & 6.47 & 3.13 & 2.92 & 2.62 \\
\hline China & $2002-2017$ & 25.80 & 14.55 & 11.08 & 1.09 & 2.68 & 2.93 & 2.80 \\
\hline Denmark & $2000-2014$ & 6.00 & 5.17 & 4.86 & 13.05 & 2.80 & 3.04 & 2.80 \\
\hline Finland & $2000-2016$ & 6.40 & 5.73 & 7.69 & 6.21 & 2.97 & 3.24 & 3.06 \\
\hline France & $2000-2017$ & 13.22 & 4.71 & 2.52 & 4.01 & 2.77 & 3.18 & 2.82 \\
\hline Germany & $2000-2017$ & 5.72 & 4.88 & 4.92 & 4.90 & 2.92 & 2.89 & 2.42 \\
\hline Greece & 2003-2017 & 10.92 & 6.79 & 12.93 & 1.22 & 2.27 & 2.04 & 1.86 \\
\hline Iceland & $2002-2010$ & 14.38 & 11.27 & 7.92 & - & 2.34 & 2.80 & 3.76 \\
\hline India & $2000-2017$ & 23.19 & 10.41 & 7.93 & 0.78 & 3.15 & 2.75 & 2.22 \\
\hline Ireland & $2000-2017$ & 8.49 & 8.40 & 7.26 & 6.18 & 2.90 & 3.08 & 2.93 \\
\hline Italy & $2000-2017$ & 8.57 & 4.51 & 4.51 & 1.66 & 2.42 & 2.25 & 1.75 \\
\hline Japan & $2000-2017$ & 2.49 & 3.46 & 6.54 & 2.40 & 2.54 & 2.88 & 2.09 \\
\hline Luxembourg & 2013-2017 & 12.47 & 8.85 & 3.17 & 7.22 & 2.51 & 3.20 & 3.22 \\
\hline Netherlands & 2001-2017 & 6.23 & 7.00 & 7.42 & 7.26 & 3.17 & 2.76 & 2.82 \\
\hline $\begin{array}{l}\text { New } \\
\text { Zealand }\end{array}$ & $2001-2005$ & 12.77 & 15.06 & 11.09 & - & 3.01 & 2.69 & 2.52 \\
\hline Nigeria & 2011-2013 & 60.69 & 36.63 & 14.26 & 1.54 & 2.06 & 1.93 & 1.83 \\
\hline Norway & $2000-2015$ & 6.64 & 7.38 & 6.42 & 8.90 & 2.71 & 2.28 & 2.58 \\
\hline Portugal & 2001-2016 & 11.75 & 7.47 & 6.59 & 3.41 & 2.70 & 2.52 & 2.09 \\
\hline Romania & 2007-2015 & 19.01 & 7.64 & 4.33 & 4.40 & 2.32 & 2.27 & 2.11 \\
\hline Russia & 2006-2016 & 3.11 & 4.26 & 2.52 & 0.60 & 2.12 & 2.31 & 2.07 \\
\hline Slovakia & 2011-2017 & 13.42 & 10.82 & 7.29 & 3.67 & 2.54 & 2.07 & 2.07 \\
\hline Slovenia & 2002-2017 & 9.97 & 5.26 & 5.41 & 5.44 & 2.42 & 2.34 & 1.96 \\
\hline South Africa & 2001-2017 & 11.04 & 7.26 & 1.97 & 0.47 & 2.64 & 2.90 & 2.08 \\
\hline South Korea & $2000-2017$ & 15.61 & 9.33 & 10.08 & 2.55 & 2.47 & 3.17 & 2.65 \\
\hline Spain & $2000-2017$ & 5.94 & 5.82 & 7.15 & 1.94 & 2.37 & 2.57 & 2.45 \\
\hline Sweden & $2000-2017$ & 10.00 & 5.54 & 5.65 & 8.12 & 2.80 & 2.43 & 2.21 \\
\hline $\begin{array}{l}\text { United } \\
\text { Kingdom }\end{array}$ & $2000-2017$ & 6.66 & 6.95 & 5.78 & 7.13 & 2.88 & 2.85 & 2.67 \\
\hline $\begin{array}{l}\text { United } \\
\text { States }\end{array}$ & $2000-2017$ & 9.87 & 11.36 & 6.81 & 6.91 & 3.37 & 2.88 & 2.72 \\
\hline
\end{tabular}


Table 6 (continued)

Economy Environmental conditions

\begin{tabular}{|c|c|c|c|c|c|c|c|c|}
\hline $\begin{array}{l}\text { Governmental } \\
\text { programs }\end{array}$ & $\begin{array}{l}\text { Basic } \\
\text { school }\end{array}$ & $\begin{array}{l}\text { Post } \\
\text { school }\end{array}$ & $\begin{array}{l}\text { R\&D } \\
\text { transfer }\end{array}$ & $\begin{array}{l}\text { Commercial and } \\
\text { professional } \\
\text { infrastructure }\end{array}$ & $\begin{array}{l}\text { Internal } \\
\text { market } \\
\text { dynamics }\end{array}$ & $\begin{array}{l}\text { Internal } \\
\text { market } \\
\text { openness }\end{array}$ & $\begin{array}{l}\text { Physical and } \\
\text { services } \\
\text { infrastructure }\end{array}$ & $\begin{array}{l}\text { Cultural and } \\
\text { social norms }\end{array}$ \\
\hline
\end{tabular}

Economy Environmental conditions

\begin{tabular}{lllllllll}
\hline $\begin{array}{l}\text { Governmental } \\
\text { programs }\end{array}$ & $\begin{array}{l}\text { Basic } \\
\text { school }\end{array}$ & $\begin{array}{l}\text { Post } \\
\text { school }\end{array}$ & $\begin{array}{l}\text { R\&D } \\
\text { transfer }\end{array}$ & $\begin{array}{l}\text { Commercial and } \\
\text { professional } \\
\text { infrastructure }\end{array}$ & $\begin{array}{l}\text { Internal } \\
\text { market } \\
\text { dynamics }\end{array}$ & $\begin{array}{l}\text { Internal } \\
\text { market } \\
\text { openness }\end{array}$ & $\begin{array}{l}\text { Physical and } \\
\text { services } \\
\text { infrastructure }\end{array}$ & $\begin{array}{l}\text { Cultural and } \\
\text { social norms }\end{array}$ \\
\hline 2.79 & 2.08 & 3.06 & 2.95 & 3.50 & 2.54 & 3.08 & 3.92 & 2.43
\end{tabular}

\begin{tabular}{|c|c|c|c|c|c|c|c|c|c|}
\hline Belgium & 2.79 & 2.08 & 3.06 & 2.95 & 3.50 & 2.54 & 3.08 & 3.92 & 2.43 \\
\hline Canada & 2.96 & 2.47 & 3.03 & 2.95 & 3.49 & 2.47 & 3.16 & 4.12 & 3.33 \\
\hline China & 2.67 & 1.89 & 2.83 & 2.67 & 2.68 & 3.94 & 2.71 & 4.06 & 3.21 \\
\hline Denmark & 3.13 & 2.50 & 2.50 & 2.63 & 3.42 & 2.60 & 2.99 & 4.02 & 2.65 \\
\hline Finland & 2.99 & 2.31 & 2.81 & 2.87 & 3.39 & 2.70 & 2.91 & 4.24 & 2.74 \\
\hline France & 3.17 & 1.73 & 3.04 & 2.81 & 3.10 & 2.89 & 2.54 & 3.97 & 2.31 \\
\hline Germany & 3.46 & 1.89 & 2.67 & 2.73 & 3.30 & 2.88 & 2.90 & 3.92 & 2.61 \\
\hline Greece & 2.06 & 1.79 & 2.47 & 2.32 & 3.01 & 2.85 & 2.44 & 3.59 & 2.53 \\
\hline Iceland & 2.70 & 2.14 & 3.15 & 2.69 & 3.20 & 3.38 & 3.04 & 4.33 & 3.89 \\
\hline India & 2.52 & 2.03 & 2.84 & 2.65 & 3.21 & 3.22 & 2.74 & 3.56 & 3.07 \\
\hline Ireland & 3.34 & 2.24 & 2.89 & 2.86 & 3.37 & 2.61 & 3.00 & 3.39 & 3.17 \\
\hline Italy & 2.28 & 1.86 & 2.70 & 2.36 & 2.76 & 2.89 & 2.54 & 3.06 & 2.53 \\
\hline Japan & 2.40 & 1.55 & 2.40 & 2.53 & 2.43 & 3.69 & 2.55 & 3.62 & 2.33 \\
\hline Luxembourg & 3.53 & 2.07 & 3.03 & 3.03 & 3.45 & 2.53 & 3.11 & 4.05 & 2.47 \\
\hline Netherlands & 3.01 & 2.72 & 3.10 & 2.68 & 3.56 & 2.88 & 3.37 & 4.27 & 3.09 \\
\hline $\begin{array}{l}\text { New } \\
\quad \text { Zealand }\end{array}$ & 2.67 & 2.21 & 2.80 & 2.49 & 3.30 & 2.73 & 3.12 & 4.04 & 3.09 \\
\hline Nigeria & 2.09 & 2.11 & 2.73 & 1.80 & 2.72 & 3.43 & 2.33 & 2.91 & 3.24 \\
\hline Norway & 2.92 & 2.42 & 2.63 & 2.70 & 3.41 & 2.59 & 2.68 & 4.02 & 2.72 \\
\hline Portugal & 2.75 & 2.00 & 2.82 & 2.60 & 3.04 & 2.55 & 2.53 & 3.81 & 2.40 \\
\hline Romania & 2.33 & 2.27 & 2.77 & 2.37 & 3.12 & 3.05 & 2.63 & 3.02 & 2.44 \\
\hline Russia & 2.09 & 2.24 & 2.89 & 2.05 & 3.05 & 3.21 & 2.26 & 3.24 & 2.58 \\
\hline Slovakia & 2.14 & 2.03 & 2.73 & 1.95 & 3.08 & 2.71 & 2.60 & 3.99 & 2.14 \\
\hline Slovenia & 2.52 & 2.08 & 2.77 & 2.31 & 2.94 & 3.09 & 2.47 & 3.77 & 2.19 \\
\hline South Africa & 2.12 & 1.95 & 2.62 & 2.09 & 2.86 & 2.74 & 2.38 & 3.20 & 2.60 \\
\hline South Korea & 2.87 & 2.00 & 2.46 & 2.46 & 2.58 & 4.01 & 2.44 & 3.86 & 3.08 \\
\hline Spain & 2.87 & 1.89 & 2.61 & 2.49 & 2.98 & 2.49 & 2.61 & 3.51 & 2.59 \\
\hline Sweden & 2.76 & 2.27 & 2.58 & 2.56 & 3.11 & 3.11 & 2.78 & 4.03 & 2.70 \\
\hline $\begin{array}{l}\text { United } \\
\quad \text { Kingdom }\end{array}$ & 2.71 & 2.18 & 2.70 & 2.56 & 3.15 & 2.85 & 3.04 & 3.74 & 2.89 \\
\hline $\begin{array}{l}\text { United } \\
\quad \text { States }\end{array}$ & 2.86 & 2.36 & 3.15 & 2.87 & 3.55 & 3.01 & 3.04 & 4.16 & 4.11 \\
\hline
\end{tabular}

Source: Global Entrepreneurship Monitor 
Open Access This article is licensed under a Creative Commons Attribution 4.0 International License, which permits use, sharing, adaptation, distribution and reproduction in any medium or format, as long as you give appropriate credit to the original author(s) and the source, provide a link to the Creative Commons licence, and indicate if changes were made. The images or other third party material in this article are included in the article's Creative Commons licence, unless indicated otherwise in a credit line to the material. If material is not included in the article's Creative Commons licence and your intended use is not permitted by statutory regulation or exceeds the permitted use, you will need to obtain permission directly from the copyright holder. To view a copy of this licence, visit http://creativecommons.org/licenses/by/4.0/.

\section{References}

The references marked with an asterisk (*) indicate the papers that were included in our analysis. The references without the asterisk were used to complement our discussion

*Abetti, P. A. (2004). Government-supported incubators in the Helsinki region, Finland: infrastructure, results, and best practices. The Journal of Technology Transfer, 29(1), 19-40.

*Acs, Z. J., Braunerhjelm, P., Audretsch, D. B., \& Carlsson, B. (2009). The knowledge spillover theory of entrepreneurship. Small Business Economics, 32(1), 15-30.

Acs, Z. J., Stam, E., Audretsch, D. B., \& O’Connor, A. (2017). The lineages of the entrepreneurial ecosystem approach. Small Business Economics, 49(1), 1-10.

*Aidis, R., Estrin, S., \& Mickiewicz, T. (2008), Institutions and entrepreneurship development in Russia: a comparative perspective. Journal of Business Venturing, 23, 656-672.

Armitage, A., \& Keeble-Allen, D. (2008). Undertaking a structured literature review or structuring a literature review: tales from the field. The Electronic Journal of Business Research Methods, 6(2), 103-114.

*Atherton, A., \& Hannon, P. D. (2006). Localised strategies for supporting incubation: strategies arising from a case of rural enterprise development. Journal of Small Business and Enterprise Development, 13(1), 48-61.

Audretsch, D. B. (2019). Have we oversold the Silicon Valley model of entrepreneurship? Small Business Economics. https://doi.org/10.1007/s11187-019-00272-4.

Audretsch, D., Belitski, M., \& Korosteleva, J. (2019). Cultural diversity and knowledge in explaining entrepreneurial outcomes in European cities. Small Business Economics. https://doi.org/10.1007/s11187-019-00191-4.

Autio, E., Kenney, M., Mustar, P., Siegel, D., \& Wright, M. (2014). Entrepreneurial innovation: the importance of context. Research Policy, 43(7), 1097-1108.
Barney, J. B., \& Harrison, J. S. (2020). Stakeholder theory at the crossroads. Business \& Society, 59(2), 203-212.

*Bateman, M (2000). Neo-liberalism, SME development and the role of business support centres in the transition economies of Central and Eastern Europe. Small Business Economics, 14, 275-298.

*Bates, T. (2015). Contested terrain: the role of preferential policies in opening government and corporate procurement markets to black-owned businesses. Du Bois Review: Social Science Research on Race, 12(1), 137-159.

*Beraza-Garmendia, J. M., \& Rodríguez-Castellanos, A. (2015). Characteristics and effectiveness of university spin-off support programmes. Academia Revista Latinoamericana de Administración, 28(1), 14-44.

*Bitzenis, A., \& Nito, E. (2005). Obstacles to entrepreneurship in a transition business environment: the case of Albania. Journal of Small Business and Enterprise Development, 12(4), 564-578.

Busenitz, L. W., West III, G. P., Shepherd, D., Nelson, T., Chandler, G. N., \& Zacharakis, A. (2003). Entrepreneurship research in emergence: past trends and future directions. Journal of Management, 29(3), 285-308.

Busenitz, L. W., Plummer, L. A., Klotz, A. C., Shahzad, A., \& Rhoads, K. (2014). Entrepreneurship research (1985-2009) and the emergence of opportunities. Entrepreneurship: Theory and Practice. https://doi.org/10.1111/etap.12120.

Bygrave, W. D., \& Hofer, C. W. (1991). Theorizing about entrepreneurship. Entrepreneurship Theory and Practice, 16(2), 13-22.

*Canton, E., Grilo, I., Monteagudo, J., \& Van der Zwan (2013). Perceived credit constraints in the European Union. Small Business Economics, 41, 701-715.

Cardon, M. S., Zietsma, C., Saparito, P., Matherne, B., \& Davis, C. (2005). A tale of passion: new insights into entrepreneurship from a parenthood metaphor. Journal of Business Venturing, 20, 23-45.

*Coad, A., \& Pawan Tamvada, J. (2012). Firm growth and barriers to growth among small firms in India. Small Business Economics, 39, 383-400.

*Coomes, P. A., Fernandez, J., \& Gohmann, S. F. (2013). The rate of proprietorship among metropolitan areas: the impact of the local economic environment and capital resources. Entrepreneurship Theory and Practice, https://doi. org/10.1111/j.1540-6520.2012.00511.x.

*Cooper, S. Y., \& Park, J. S. (2008). The impact of 'incubator' organizations on opportunity recognition and technology innovation in new, entrepreneurial high-technology ventures. International Small Business Journal, 26(1), 27-56.

Cornelius, B., Landström, H., \& Persson, O. (2006). Entrepreneurial studies: the dynamic research front of a developing social science. Entrepreneurship: Theory and Practice, 30(3), 375-398.

Crowley-Henry, M., O’Connor, E., \& Al Ariss, A. (2018). Portrayal of skilled migrants' careers in business and management studies: a review of the literature and future research agenda. European Management Review, 15(3), 375-394. 
Davidsson, P. (2006). Nascent entrepreneurship: empirical studies and developments. Foundations and Trends in Entrepreneurship Research, 2(1), 1-76.

*Davidsson, P. \& Gordon, S. R. (2016). Much ado about nothing? The surprising persistence of nascent entrepreneurs through macroeconomic crisis. Entrepreneurship Theory and Practice, 40(4), 915-941.

*Davidsson, P., \& Henrekson, M. (2002). Determinants of the prevalence of start-ups and high-growth firms. Small Business Economics, 19, 81-104.

De Fuentes, C., Santiago, F., \& Temel, S. (2020). Perception of innovation barriers by successful and unsuccessful innovators in emerging economies. The Journal of Technology Transfer, 45(4), 1283-1307.

*Degeorge, J. M., \& Fayolle, A. (2011). The entrepreneurial process trigger: a modelling attempt in the French context. Journal of Small Business and Enterprise Development, 18(2), 251-277.

Dencker, J., Bacq, S. C., Gruber, M., \& Haas, M. (2019). Reconceptualizing necessity entrepreneurship: a contextualized framework of entrepreneurial processes under the condition of basic needs. Academy of Management Review. https://doi.org/10.5465/amr.2017.0471.

DeTienne, D. R. (2010). Entrepreneurial exit as a critical component of the entrepreneurial process: theoretical development. Journal of Business Venturing, 25(2), 203-215.

*Edelman, L., \& Yli-Renko, H. (2010). The impact of environment and entrepreneurial perceptions on venture-creation efforts: bridging the discovery and creation views of entrepreneurship. Entrepreneurship Theory and Practice, 34(5), 833-856.

*Edoho, F. M. (2015). Entrepreneurship and socioeconomic development: catalyzing African transformation in the $21 \mathrm{st}$ century. African Journal of Economic and Management Studies, 6(2), 127-147.

Eesley, C. E., Eberhart, R. N., Skousen, B. R., \& Cheng, J. L. (2018). Institutions and entrepreneurial activity: the interactive influence of misaligned formal and informal institutions. Strategy Science, 3(2), 393-407.

*El-Harbi, S., \& Anderson, A. R. (2010). Institutions and the shaping of different forms of entrepreneurship. The Journal of Socio-Economics, 39(3), 436-444.

*Elston, J. A., Chen, S., \& Weidinger, A. (2016). The role of informal capital on new venture formation and growth in China. Small Business Economics, 46, 79-91.

*Falavigna, G., Ippoliti, R., \& Manello, A. (2017). Judicial efficiency and immigrant entrepreneurs. Journal of Small Business Management. https://doi.org/10.1111/jsbm.12376.

Frid, C. J., Wyman, D. M., \& Coffey, B. (2016). Effects of wealth inequality on entrepreneurship. Small Business Economics, 47(4), 895-920.

*García-Posada, M., \& Mora-Sanguinetti, J. S. (2015). Entrepreneurship and enforcement institutions: disaggregated evidence for Spain. European Journal of Law and Economics, 40(1), 49-74.
Gartner, W. B. (1990). What are we talking about when we talk about entrepreneurship? Journal of Business Venturing, 5(1), $15-28$.

*Gartner, W. and Liao, J. (2012). The effects of perceptions of risk, environmental uncertainty, and growth aspirations on new venture creation success. Small Business Economics, 39(3), 703-712.

Gartner, W. B., Gartner, W. C., Shaver, K. G., Carter, N. M., \& Reynolds, P. D. (Eds.). (2004). Handbook of entrepreneurial dynamics: the process of business creation. Sage.

*Gawel, A., \& Toikko, T. (2014). Entrepreneurial processes in new company creation: an examination of private companies in the social service sector. Journal of Enterprising Communities: People and Places in the Global Economy, 8(3), 198-216.

George, N. M., Parida, V., Lahti, T., \& Wincent, J. (2016). A systematic literature review of entrepreneurial opportunity recognition: insights on influencing factors. International Entrepreneurship and Management Journal, 12(2), 309350 .

*Gohmann, S. F. (2012). Institutions, latent entrepreneurship, and self-employment: an international comparison. Entrepreneurship Theory and Practice, 36(2), 295-321.

*González-Pernía, J. L., Kuechle, G., \& Peña-Legazkue, I. (2013). An assessment of the determinants of university technology transfer. Economic Development Quarterly, 27(1), 6-17.

Guerrero, M., \& Peña-Legazkue, I. (2019). Renascence after postmortem: the choice of accelerated repeat entrepreneurship. Small Business Economics, 52(1), 47-65.

Guerrero, M., \& Urbano, D. (2019a). A research agenda for entrepreneurship and innovation: the role of entrepreneurial universities. In D. B. Audretsch, E. E. Lehmann, \& A. Link (Eds.), Elgar Research Agendas, A Research Agenda for Entrepreneurship and Innovation, 107-133. Inc.: Edward Elgar Publishing.

Guerrero, M., \& Urbano, D. (2019b). Effectiveness of technology transfer policies and legislation in fostering entrepreneurial innovations across continents: an overview. The Journal of Technology Transfer. https://doi.org/10.1007/s10961-01909736-x.

Guerrero, M., Amorós, J. E., \& Urbano, D. (2019). Do employees' generational cohorts influence corporate venturing? A multilevel analysis. Small Business Economics. https://doi. org/10.1007/s11187-019-00304-z.

Guerrero, M., \& Espinoza-Benavides, J. (2020). Does entrepreneurship ecosystem influence business re-entries after failure? International Entrepreneurship and Management Journal. https://doi.org/10.1007/s11365-020-00694-7.

Gundolf, K., \& Filser, M. (2013). Management research and religion: a citation analysis. Journal of Business Ethics, 112(1), 177-185.

* Gupta, V. K. (2016). Entrepreneurial orientation and firm performance in Indian SMEs: universal and contingency perspectives. International Small Business Journal, 34(5), 660-682.

*Guzmán, J. \& Rodríguez, M. J. (2008). Behaviour of the woman entrepreneur: a global perspective. Revista de Economía Mundial, 18, 381-392. 
*Hannibal, M., Evers, N., \& Servais, P. (2016). Opportunity recognition and international new venture creation in university spin-offs - cases from Denmark and Ireland. Journal of International Entrepreneurship, 14(3), 345-372.

*Hassink, H., Grin, J., \& Hulsink, W. (2016). Identity formation and strategy development in overlapping institutional fields. Different entry \& alignment strategies of regional organizations of care farms into the healthcare domain. Journal of Organizational Change Management, 29 (6), 973-993.

*Heinonen, J., \& Hytti, U. (2016). Entrepreneurship mission and content in Finnish policy programmes. Journal of Small Business and Enterprise Development, 23(1), 149-162.

Henrekson, M., \& Sanandaji, T. (2019). Measuring entrepreneurship: do established metrics capture Schumpeterian entrepreneurship? Entrepreneurship Theory and Practice. https://doi. org/10.1177/1042258719844500.

Hindle, K. (2010). How community context affects entrepreneurial process: a diagnostic framework. Entrepreneurship and Regional Development, 22(7-8), 599-647.

Hofmann, E. T. (2018). Labor market integration of returned educational migrants in Turkmenistan. Post-Soviet Affairs, 34(1), 1-16.

*Honig, B., \& Karlsson, T. (2004). Institutional forces and the written business plan. Journal of Management, 30(1), 29-48.

*Hopp, C. (2015). Does the presence of a formal business plan increase formal financial support? Empirical evidence from the PSED II on the signalling and mimetic nature of formal business planning. Applied Economics Letters, 22(9), 673678.

Iversen, J., Jørgensen, R., \& Malchow-Møller, N. (2007). Defining and measuring entrepreneurship. Foundations and Trends in Entrepreneurship, 4(1), 1-63.

*Jabani Mambula, C. (2004) Relating external support, business growth \& creating strategies for survival: a comparative case study analyses of small manufacturing firms (SMFs) and entrepreneurs. Small Business Economics 22: 83-109.

Jack, S. L., \& Anderson, A. R. (2002). The effects of embeddedness on the entrepreneurial process. Journal of Business Venturing, 17(5), 467-487.

*Johansson, D. (2004). Is small beautiful? The case of the Swedish I.T. industry. Entrepreneurship \& Regional Development, $16,271-287$.

Jones, M. V., \& Coviello, N. E. (2005). Internationalisation: conceptualising an entrepreneurial process of behaviour in time. Journal of International Business Studies, 36(3), 284303.

Jones, M. V., Coviello, N., \& Tang, Y. K. (2011). International entrepreneurship research (1989-2009): a domain ontology and thematic analysis. Journal of Business Venturing, 26(6), 632-659.

*Kairiza, T., Kiprono, P., \& Magadzire, V. (2017). Gender differences in financial inclusion amongst entrepreneurs in Zimbabwe. Small Business Economics, 48, 259-272.

*Kang, J. W., \& Heshmati, A. (2008). Effect of credit guarantee policy on survival and performance of SMEs in the Republic of Korea. Small Business Economics, 31, 445-462.
*Karlsson, T., Honig, B., Welter, F., Shakked, L., \& Sadaovski, A. (2005). A cross-national comparison of incubated organizations: an institutional perspective. In International entrepreneurship (pp. 165-184). Emerald Group Publishing Limited.

Karlsson, C., Rickardsson, J., \& Wincent, J. (2019). Diversity, innovation and entrepreneurship: where are we and where should we go in future studies? Small Business Economics, $1-14$.

Knox, E., \& Egbe, C. E. (2018). Mediating and moderating correlates and socioeconomic factors in firm creation among nascent entrepreneurs. The Business \& Management Review, 9(3), 395-395.

Korunka, C., Frank, H., Lueger, M., \& Mugler, J. (2003). The entrepreneurial personality in the context of resources, environment, and the start-up process - a configurational approach. Entrepreneurship Theory and Practice, 28(1), 2342.

*Krasniqi, B. A., \& Desai, S. (2016). Institutional drivers of highgrowth firms: country-level evidence from 26 transition economies. Small Business Economics, 47, 1075-1094.

Kraus, S., Filser, M., O’Dwyer, M., \& Shaw, E. (2014). Social entrepreneurship: an exploratory citation analysis. Review of Managerial Science, 8(2), 275-292.

*Lebusa, M. J. (2014). Entrepreneurial intention in advanced undergraduate students. Mediterranean Journal of Social Sciences, 5(27 P2), 760.

Liñán, F., \& Fayolle, A. (2015). A systematic literature review on entrepreneurial intentions: citation, thematic analyses, and research agenda. International Entrepreneurship and Management Journal, 11(4), 907-933.

*LiPuma, J. A., Newbert, S. L., \& Doh, J. P. (2013). The effect of institutional quality on firm export performance in emerging economies: a contingency model of firm age and size. Small Business Economics, 40, 817-841.

Lourenço, F., \& Jones, O. (2006). Developing entrepreneurship education: comparing traditional and alternative teaching approaches. International Journal of Entrepreneurship Education, 4(1), 111-140.

*Lutz, C. H., Kemp, R. G., \& Dijkstra, S. G. (2010). Perceptions regarding strategic and structural entry barriers. Small Business Economics, 35(1), 19-33.

*Mair, J., \& Marti, I. (2007). Entrepreneurship for social impact: encouraging market access in rural Bangladesh. Corporate Governance, 7(4), 493-501.

*McEwan, G. (2015). Delivering entrepreneurship training and support. Local Economy, 30(5), 568-576.

*Meek, W. R., Pacheco, D. F., \& York, J. G. (2010). The impact of social norms on entrepreneurial action: evidence from the environmental entrepreneurship context. Journal of Business Venturing, 25(5), 493-509.

*Meintjes, A., Henrico, A., \& Kroon, J. (2015). Teaching problem-solving competency in Business Studies at secondary school level. South African Journal of Education, 35(3).

Mergemeier, L., Moser, J., \& Flatten, T. C. (2018). The influence of multiple constraints along the venture creation process and on start-up intention in nascent entrepreneurship. Entrepreneurship and Regional Development, 1-29. 
*Miner, A. S., Gong, Y., Ciuchta, M. P., Sadler, A., \& Surdyk, J. (2012). Promoting university start-ups: international patterns, vicarious learning and policy implications. The Journal of Technology Transfer, 37(2), 213-233.

*Misra, K., Memili, E., Welsh, D. H., \& Sarkar, S. (2014). The determinants of venture creation time: a cross-country perspective. International Entrepreneurship and Management Journal, 10(2), 253-276.

Morris, M. H., Lewis, P. S., \& Sexton, D. L. (1994). Reconceptualizing entrepreneurship: an input-output perspective. Advanced Management Journal, 59(1), 21.

Mueller, P. (2006). Entrepreneurship in the region: breeding ground for nascent entrepreneurs? Small Business Economics, 27(1), 41-58.

Nabi, G., Liñán, F., Fayolle, A., Krueger, N., \& Walmsley, A. (2017). The impact of entrepreneurship education in higher education: a systematic review and research agenda. Academy of Management Learning \& Education, 16(2), 277-299.

Nabi, G., Walmsley, A., Liñán, F., Akhtar, I., \& Neame, C. (2018). Does entrepreneurship education in the first year of higher education develop entrepreneurial intentions? The role of learning and inspiration. Studies in Higher Education, 43(3), 452-467.

Nambisan, S., Wright, M., \& Feldman, M. (2019). The digital transformation of innovation and entrepreneurship: progress, challenges and key themes. Research Policy. https://doi. org/10.1016/j.respol.2019.03.018.

*Patton, D. (2014). Realising potential: the impact of business incubation on the absorptive capacity of new technologybased firms. International Small Business Journal, 32(8), 897-917.

*Pilegaard, M., Moroz, P. W., \& Neergaard, H. (2010). An autoethnographic perspective on academic entrepreneurship: implications for research in the social sciences and humanities. Academy of Management Perspectives, 241), 46-61.

*Pinillos, M. J., \& Reyes, L. (2011). Relationship between individualist-collectivist culture and entrepreneurial activity: evidence from Global Entrepreneurship Monitor data. Small Business Economics, 37(1), 23-37.

Pittaway, L., \& Cope, J. (2007). Entrepreneurship education a systematic review of the evidence. International Small Business Journal, 25(5), 479-510.

Podsakoff, P., MacKenzie, S., Bachrach, D., \& Podsakoff, N. (2005). The influence of management journals in the $1980 \mathrm{~s}$ and 1990s. Strategic Management Journal, 26, 473-488.

*Popescu, C. C., Bostan, I., Robu, I. B., \& Maxim, A. (2016). An analysis of the determinants of entrepreneurial intentions among students: a Romanian case study. Sustainability, $8(8), 771$.

*Puffer, S. M., McCarthy, D. J., \& Boisot, M. (2010). Entrepreneurship in Russia and China: the impact of formal institutional voids. Entrepreneurship Theory and Practice, 32, 441-467.

*Rasmussen, E., \& Borch, O. J. (2010). University capabilities in facilitating entrepreneurship: a longitudinal study of spin-off ventures at mid-range universities. Research Policy, 39(5), 602-612.

Rauch, A. (2019). Opportunities and threats in reviewing entrepreneurship theory and practice. Entrepreneurship Theory and Practice. https://doi.org/10.1177/1042258719879635.

Reynolds, P. D., \& White, S. B. (1997). The entrepreneurial process: economic growth, men, women, and minorities. Westport: Quorum Books.

*Rodríguez-Gulías, M. J., Fernández-López, S., \& Rodeiro-Pazos, D. (2016). Growth determinants in entrepreneurship: a longitudinal study of Spanish technology-based university spinoffs. Journal of International Entrepreneurship, 14(3), 323344.

*Rotefoss, B., \& Kolvereid, L. (2005). Aspiring, nascent and fledgling entrepreneurs: an investigation of the business start-up process. Entrepreneurship \& Regional Development, 17(2), 109-127.

*Rusinovic, K. (2008). Moving between markets? Immigrant entrepreneurs in different markets. International Journal of Entrepreneurial Behaviour \& Research, 14(6), 440-454.

*Schiopu, A. F., Vasile, D. C., \& Tuclea, C. E. (2015). Principles and best practices in successful tourism business incubators. Economic Journal, 17(38), 474-487.

Schumpeter, J. A. (1934). The theory of economic development. In New Brunswick, NJ, and London. UK: Transaction Publishers.

*Shakhovskaya, L. S., \& Akimova, O. E. (2013). Motivation vector of business development in contemporary Russia. World Applied Sciences Journal, 22 (5), 738-746.

Stevenson, H. H., \& Jarillo, J. C. (1990). A paradigm of entrepreneurship: entrepreneurial management. Strategic Management Journal, 17-27.

*Szabo, Z. K., \& Herman, E. (2014). Productive entrepreneurship in the E.U. and its barriers in transition economies: a cluster analysis. Acta Polytechnica Hungarica, 11(6), 73-94.

Tranfield, D. R., Denyer, D., \& Smart, P. (2003). Towards a methodology for developing evidence-informed management knowledge by means of systematic review. British Journal of Management, 14, 207-222.

United Nations. (2017). Country classification. Washington: United Nations.

Urbano, D., Aparicio, S., \& Audretsch, D. (2019). Twenty-five years of research on institutions, entrepreneurship, and economic growth: what has been learned? Small Business Economics, 53(1), 21-49.

van Stel, A., Lyalkov, S., Millán, A., \& Millan, J. M. (2019). The moderating role of IPR on the relationship between countrylevel R\&D and individual-level entrepreneurial performance. Journal of Technology Transfer. https://doi.org/10.1007 /s10961-019-09731-2.

*Wallin, A., Still, K., \& Henttonen, K. (2016). Entrepreneurial growth ambitions: the case of Finnish technology start-ups. Technology Innovation Management Review, 6(10), 5-16.

Wallmeroth, J., Wirtz, P., \& Groh, A. P. (2018). Venture capital, angel financing, and crowdfunding of entrepreneurial ventures: a literature review. Foundations and Trends in Entrepreneurship, 14(1), 1-129. 
*Wang, C. L., \& Altinay, L. (2010): Social embeddedness, entrepreneurial orientation and firm growth in ethnic minority small businesses in the U.K. International Small Business Journal, 30(1), 3-23.

Welter, F. (2011). Contextualizing entrepreneurship - conceptual challenges and ways forward. Entrepreneurship Theory and Practice, 35(1), 165-184.

Welter, F., Baker, T., Audretsch, D. B., \& Gartner, W. B. (2017). Everyday entrepreneurship - a call for entrepreneurship research to embrace entrepreneurial diversity. Entrepreneurship Theory and Practice. https://doi. org/10.1111/etap.12258.

*Williams, N., \& Huggins, R. (2013). Supporting entrepreneurship in deprived communities: a vision too far? Journal of Small Business and Enterprise Development, 20(1), 165180.

Wright, M., Siegel, D. S., \& Mustar, P. (2017). An emerging ecosystem for student start-ups. The Journal of Technology Transfer, 42(4), 909-922.
Xi, J. M., Kraus, S., Filser, M., \& Kellermanns, F. W. (2013). Mapping the field of family business research: past trends and future directions. International Entrepreneurship and Management Journal, 11(1), 113-132.

*Yusuf, J. E. (2010). Meeting entrepreneurs' support needs: are assistance programs effective? Journal of Small Business and Enterprise Development, 17(2), 294-307.

*Zahra, S. A., \& Nambisan, S. (2012). Entrepreneurship and strategic thinking in business ecosystems. Business Horizons, 55(3), 219-229.

*Zhang, Y. (2015). The contingent value of social resources: entrepreneurs' use of debt-financing sources in Western China. Journal of Business Venturing 30, 90-406.

Publisher's note Springer Nature remains neutral with regard to jurisdictional claims in published maps and institutional affiliations. 